\title{
Dust events in Beijing, China (2004-2006): comparison of ground-based measurements with columnar integrated observations
}

\author{
Z. J. Wu ${ }^{1,2}$, Y. F. Cheng ${ }^{2}$, M. Hu ${ }^{1}$, B. Wehner ${ }^{2}$, N. Sugimoto ${ }^{3}$, and A. Wiedensohler ${ }^{2}$ \\ ${ }^{1}$ State Key Joint Laboratory of Environmental Simulation and Pollution Control, College of Environmental Sciences and \\ Engineering, Peking University, Beijing, China \\ ${ }^{2}$ Leibniz-Institute for Tropospheric Research, 04318 Leipzig, Germany \\ ${ }^{3}$ Atmospheric Environment Division, National Institute for Environmental Studies, Tsukuba, Japan
}

Received: 9 January 2009 - Published in Atmos. Chem. Phys. Discuss.: 14 May 2009

Revised: 25 August 2009 - Accepted: 7 September 2009 - Published: 22 September 2009

\begin{abstract}
Ambient particle number size distributions spanning three years were used to characterize the frequency and intensity of atmospheric dust events in the urban areas of Beijing, China in combination with AERONET sun/sky radiometer data. Dust events were classified into two types based on the differences in particle number and volume size distributions and local weather conditions. This categorization was confirmed by aerosol index images, columnar aerosol optical properties, and vertical potential temperature profiles. During the type- 1 events, dust particles dominated the total particle volume concentration $(<10 \mu \mathrm{m})$, with a relative share over $70 \%$. Anthropogenic particles in the Aitken and accumulation mode played a subordinate role here because of high wind speeds $\left(>4 \mathrm{~m} \mathrm{~s}^{-1}\right)$. The type- 2 events occurred in rather stagnant air masses and were characterized by a lower volume fraction of coarse mode particles (on average, 55\%). Columnar optical properties showed that the superposition of dust and anthropogenic aerosols in type-2 events resulted in a much higher AOD (average: 1.51) than for the rather pure dust aerosols in type-1 events (average AOD: 0.36). A discrepancy was found between the groundbased and column integrated particle volume size distributions, especially for the coarse mode particles. This discrepancy likely originates from both the limited comparability of particle volume size distributions derived from Sun photometer and in situ number size distributions, and the inhomogeneous vertical distribution of particles during dust events.
\end{abstract}

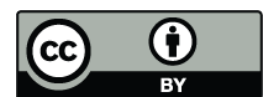

Correspondence to: $\mathrm{M} . \mathrm{Hu}$ (minhu@pku.edu.cn)

\section{Introduction}

Dust particles emitted from dry soil surfaces contribute significantly to the particle mass loading in the atmosphere, especially, near deserts and arid/semi-arid areas. Currently estimated annual global emissions of dust particles are between 1000 and $2150 \mathrm{Tg}$ (Zender, et al., 2004). These dust particles have been found to affect the global climate by altering the radiative balance of the atmosphere (Tegen et al., 2004), or through their interactions with liquid and ice clouds (Rosenfeld et al., 2001). The long-range transport and deposition of dust particles influences both biogeochemical cycles in the oceans (Gao et al., 1997; Mahowald et al., 2005; Zhang and Gao, 2007) and terrestrial ecosystems (Okin et al., 2004; Boy and Wilcke, 2008). In the global troposphere, dust particles play an important role as a reactive surface and impact atmospheric photochemistry (Dentener et al., 1996). They also have implications for human health (e.g. Griffin and Kellogg, 2004; Meng and Lu, 2007).

East Asia is one of the most important source areas of dust particles over the Northern Hemisphere (Tanaka and Chiba, 2006). During the spring season, dust storm events frequently occurred in the Sand desert, Gobi desert, and Loess plateau in Northern China and Mongolia (Zhang et al., 2003; Gong and Zhang, 2008; Yang, et al., 2008). These events cause natural disasters including sufferings of animals, plants, and human activities, especially in/near the source regions (Yang et al., 1997). A great amount of dust particles is transported over long distances to the eastern parts of China, Korea, Japan, and the Pacific Ocean (In and Park, 2002; Kurosaki and Mikami, 2003; Jo et al., 2007, etc.), and even to the west coastal area of North America (Husar et al., 2001). They negatively influence the air quality

Published by Copernicus Publications on behalf of the European Geosciences Union. 
of the urban and rural areas along the track of dust storms (In and Park, 2002; Han et al., 2007).

Beijing, the capital of China, with 17 million residents, suffers from dust storms every year due to its location downwind of Asian dust source regions. Typically, the dust storms lead to high mass concentration of $\mathrm{PM}_{10}$ (particle with aerodynamic diameter below $10 \mu \mathrm{m}$ ) and low visibility in Beijing (Zhang et al., 2003, 2005; Wang et al., 2006, etc.). Over the past decade, dust events in Beijing were of great concern by researchers. Their studies on dust particles involved mass concentration measurements (e.g., Chan and Yao, 2008), water-soluble fraction detection (e.g., Wang et al., 2005), and elemental and mineralogical analysis (e.g., Guo et al., 2004; Sun et al., 2005; Zhang et al., 2005; Shao et al., 2007, etc.) which have been intensively carried out. However, to date, only few investigations of particle number size distributions during the dust events have been performed in Beijing (e.g., Zhang et al., 2000, 2003). Moreover, such measurements with a low size resolution were often limited to particles larger than $300 \mathrm{~nm}$. Investigations on the number size distributions of dust particles in other location, which were also affected by the Asian dust storms, were limited, too. And, they were mainly performed in Korea (Park and Kim, 2006; Kim et al., 2007; Lee and Cho, 2007), which however only focused on the individual cases. The limited information on the number size distributions of dust particles hampers our current understanding of their effects, in particular, their effects on visibility, radiative forcing, and human health.

To obtain statistically representative particle number size distributions and concentration levels to support climate/radiative modeling and epidemiological studies, threeyear measurements of the number size distributions of particles diameters from $3 \mathrm{~nm}$ to $10000 \mathrm{~nm}$ were conducted in the urban areas of Beijing since March 2004. During the measuring period, 18 dust events have been observed. In the present study, number size distributions and number concentration levels of dust particles in the urban areas of Beijing are summarized and parameterized based on the long-term observation. The particle number size distributions before, during, and after the events are compared to gain insights into the interactions between dust particles and urban anthropogenic particulate matters in the urban atmosphere. At last, optical properties of dust particles and their effects on the impairment of visibility in Beijing are investigated based on AERONET dataset and the optical simulations using the measured particle number size distributions.

\section{Methods}

\subsection{Measurement site}

The measurement instruments were installed on the roof of an academic building ( $20 \mathrm{~m}$ above the ground level) on the campus of Peking University (PKU site, $39.99^{\circ} \mathrm{N}$, $116.31^{\circ} \mathrm{E}$ ). The campus is located in the northwestern urban area of Beijing and outside the cities' fourth-ring road. East of the site is a major road with heavy traffic. North and northwest of the site lays the main part of campus, without significant emission sources. More details about the measurement site and the map of the location can be found in Wu et al. (2008).

\subsection{Particle number size distributions and meteorologi- cal parameters}

Particle number size distributions with diameters between $3 \mathrm{~nm}$ and $10 \mu \mathrm{m}$ have been measured for three years since March 2004. A TDMPS (Twin Differential Mobility Particle Sizer) System, consisting of two Hauke-type DMAs (Differential Mobility Analyzer) and two CPCs (Condensational Particle Counter, model 3010 and model 3025, TSI Inc., St. Paul, USA), was used to measure the particle number size distributions from 3 to $800 \mathrm{~nm}$ (mobility diameter). Concurrently, an APS (Aerodynamic Particle Sizer, model 3321, TSI Inc., St. Paul, USA) measured the number size distributions between $800 \mathrm{~nm}$ and $10 \mu \mathrm{m}$ (aerodynamic diameter). A low flow $\mathrm{PM}_{10}$ inlet is used for both systems. The collection coefficient of $\mathrm{PM}_{10}$ inlet reported by VanOsdell (1991) was used to correct the APS dataset. The relative humidity within the system was kept below $30 \%$ by adding a silica-gel dryer in the inlet line and also in the sheath air cycle. Size distributions were measured every $10 \mathrm{~min}$. Size-dependent diffusional and gravitational losses of the particles in the inlet lines were estimated using the empirical functions given by Willeke and Baron (1993).

A meteorological station has been operated simultaneously to monitor meteorological parameters, including wind speed and direction, relative humidity (RH), air temperature. This station is about $400 \mathrm{~m}$ away from the PKU site and is mounted on top of a $20 \mathrm{~m}$ high building.

\subsection{Merging TDMPS and APS size distributions}

In order to merge the particle number size distributions obtained from TDMPS and APS, the aerodynamic diameters measured by APS were converted to the volume equivalent diameter by using the following equation (Hinds, 1982):

$D_{v e}=D_{a} \sqrt{\chi \frac{\rho_{0}}{\rho_{p}} \frac{C_{c}\left(D_{a}\right)}{C_{c}\left(D_{v e}\right)}}$

where $D_{v e}$ and $D_{a}$ are the volume equivalent diameter and the aerodynamic diameter, respectively; $C_{c}$ is the Cunningham slip correction factor; $\rho_{p}$ is the density of the particle; $\rho_{0}$ is the reference density $\left(1 \mathrm{~g} \mathrm{~cm}^{-3}\right)$; and $\chi$ is the shape factor. Here, $C_{c}\left(D_{a}\right)$ is equal to $C_{c}\left(D_{v e}\right)$ due to the particles 
measured by APS are in the Continuum regime. Therefore, Eq. (1) becomes (DeCarlo et al., 2004):

$$
D_{v e}=D_{a} \sqrt{\chi \frac{\rho_{0}}{\rho_{p}}}
$$

In the present study, the particle density $\left(\rho_{p}\right)$ during the dust events was assumed to be $2.6 \mathrm{~g} \mathrm{~cm}^{-3}$ (Park and In, 2003). The coarse particles $(>1 \mu \mathrm{m})$ measured by APS were considered to show irregular shape. Information on the shape factor of Asian dust particles is very rare in the literature. The shape factor $(\chi)$ here was therefore assumed to be 1.2 according to studies on the Saharan dust (Schladitz et al., 2009). Fine particles measured by TDMPS were assumed to be spherical, therefore, the unit shape factor was applied. This means that the mobility diameter of particles within the size range of 3 to $800 \mathrm{~nm}$ is equivalent to the volume equivalent diameter. During non-dust days, particles within the full size range $(3-10000 \mathrm{~nm})$ have been considered to be spherical with a density of $1.7 \mathrm{~g} \mathrm{~cm}^{-3}$.

After merging, the particle number size distributions were integrated to calculate particle number, surface area, and volume concentrations in different size classes. In this study, the diameter ranges for nucleation mode, Aitken mode, accumulation mode, and coarse mode were defined to be $3-20 \mathrm{~nm}$, $20-100 \mathrm{~nm}, 100-1000 \mathrm{~nm}$, and $1-10 \mu \mathrm{m}$, respectively, which have been shown earlier to best represent these modes in the urban atmosphere of Beijing (Wu, et al., 2008). The particle surface area and volume concentrations were calculated using the measured number size distributions by assuming spherical particles.

\subsection{Parameterization of particle number size distribu- tions}

Here, a least squares fitting algorithm was used to parameterize the particle number size distributions by a multiple lognormal function (Birmili, et al., 2001). The main purpose is to quantitatively describe the particle number size distributions and to allow straightforward comparisons between different aerosol particle data sets (Hussein et al., 2005). Four modes ( $i=1,2,3$, and 4$)$ were used corresponding to the nucleation mode, Aitken mode, accumulation mode, and coarse mode, respectively. Each lognormal mode was described by its total particle number concentration $\left(N_{t, i}\right)$, the geometric mean diameter (GMD, $\overline{D p_{i}}$ ), and the geometric mean standard deviation $\left(\sigma_{i}\right)$.

\subsection{Calculation of aerosol extinction and visibility}

Even though the dust particles are considered to be characterized by an irregular shape, in the present study, we would like to simply estimate the evolution of visibility during the dust events in Beijing. Therefore, the spherical Mie model (BHMIE) (Bohren and Huffman, 1998) was used to calculate the particle extinction based on the measured dry particle number size distribution $(\mathrm{RH}<30 \%)$. However, as we discussed above, the shape factor 1.2 has been taken into account when converting the aerodynamic particle diameter to the volume equivalent diameter. The volume equivalent diameters were used in the optical calculations. The average RH during the dust events was mostly lower than $30 \%$. Particle hygroscopic growth factor at $\mathrm{RH}=40 \%$ in Beijing did not exceed 1.01 in January 2005 and the particles did not show obvious growth below RH 60\% (Meier, et al., 2009). Therefore, the hygroscopic growth of the particles was not considered in the Mie calculations.

A time series of the optical equilibrium effective refractive index was derived from an aerosol optical closure study based on in-situ intensive observation in January 2005 at the PKU site. The average of the retrieved values was 1.52 $0.025 i(450-700 \mathrm{~nm})$ which resulted from an optimum fit between the measured and simulated particle scattering and absorption coefficients and was applied as the refractive index of fine particles during both dust and non-dust events. $1.53-0.005 i$ has been assumed as typical refractive index for dust particles (Dey et al., 2004). Sokolik and Toon (1999) suggested that the imaginary part for dust with $1 \%$ Fe lies somewhere near $0.001 i$ at $550 \mathrm{~nm}$. Fe has been found to contribute about $3.7 \%$ to the composition of dust particles during the dust storm events in Beijing (Sun et al., 2005). Accounting that there could be some elemental carbon (EC) attached to the coarse particles, the real part and imaginary part of coarse mode particles were assumed to be $1.58-0.005 i$ for the dust events in Beijing. This value is also within the refractive index range for dust/residual particles given in the literature (Hasan and Dzubay, 1983; Kent et al., 1983; Sloane, 1983, 1984, 1986; Hänel, 1987; Sloane et al., 1991; Tang and Munkelwitz, 1994; Redemann et al., 2000, etc.). However, the dust particle concentration should be lower during nondust periods, so the imaginary part was assumed to $0.002 i$ instead of $0.005 i$.

According to the formulae introduced by Fröhlich and Shaw (1980) and Tomasi et al. (2005), the average Rayleigh scattering coefficients of gases $\left(\sigma_{s g}\right)$ has been estimated to be about $12 \mathrm{Mm}^{-1}$ according to the recorded ambient temperature and pressure. Absorption of visible light by gases $\left(\sigma_{a g}\right)$ is considered to be essential due to $\mathrm{NO}_{2}$ (Groblicki et al., 1981). The average concentration level of $\mathrm{NO}_{2}$ in Beijing during winter and spring time was estimated to about $30 \mathrm{ppbv}$ (Cheng et al., 2008). Therefore, $\sigma_{s g}$ at $550 \mathrm{~nm}$ was calculated to be about $10 \mathrm{Mm}^{-1}$ with $\sigma_{a g}=0.33 *\left[\mathrm{NO}_{2}\right]$ (Groblicki et al., 1981). Consequently, an upper limit of the visibility $\left(L_{v}, \mathrm{~km}\right)$ can be estimated, using the total light extinction of particles and gases $\left(\sigma_{e}=\sigma_{e p}+\sigma_{s g}+\sigma_{a g}, \mathrm{Mm}^{-1}\right)$ and a modified Koschmieder relation of $L_{v}=1.9 \times 10^{3} / \sigma_{e}$ (Griffing, 1980; Husar et al., 2000; Schichtel et al., 2001; Carrico et al., 2003). The Koschmieder constant of 1.9 is about half of the standard value (3.92) (Seinfeld and Pandis, 1998). The factor of two reduction considers the fact that real 
visual targets are not black, that they are frequently too small in size, and that they are located only at quantized distances away from the observer (Griffing, 1980).

\subsection{AERONET and NASA TOMS data}

In this study, we used the total column aerosol optical properties, including the aerosol optical depth (AOD at a wavelength of $440 \mathrm{~nm})$, the Ångström exponent $\left(\stackrel{\circ}{a}_{440}-870 \mathrm{~nm}\right)$, the refractive index at the wavelength of 441, 675, 870, and $1020 \mathrm{~nm}$, and the retrieved aerosol volume size distributions provided by the Beijing AERONET station $\left(39.997^{\circ} \mathrm{N}\right.$, $116.381^{\circ} \mathrm{E}$ ) to characterize the optical features of the dust events in Beijing. Details about instrumentation, data acquisition, retrieval algorithms, calibration procedure, and accuracy can be found in the literature (e.g., Eck et al., 1999, 2001; Holben et al., 2001), and are therefore not provided here. The level-2 cloud-screened data (Smirnov et al., 2000) were used. In addition, the AERONET data (AOD and Ångström exponent) were rechecked by combining with lidar data from Beijing (Sino-Japan Friendship Center for Environmental Protection, 39.90 N, 117.16E). Those data containing cloud contaminations were excluded from the future analysis.

The aerosol index (AI) images (http://macuv.gsfc.nasa. gov/) derived from the Total Ozone Mapping Spectrometer (TOMS) were used to identify the source regions for the dust particles. TOMS AI is a qualitative indicator of ultraviolet absorbing aerosols. Dust particles belong to ultraviolet absorbing aerosols, hence yield positive values.

\section{Results and discussion}

\subsection{Identification of dust events in Beijing}

The dust events during the springs of 2004-2006 which will be discussed in the present study were identified according to:

(1) Volume concentration of the coarse mode particles: Typically, the invasion of the dust causes a higher concentration of coarse particles in the urban atmosphere. Therefore, the most obvious direct evidence for identification of dust events is the significant increase in the coarse particle concentrations. Therefore, we took the upper $95 \%$ confidence limit $\left(75 \mu \mathrm{m}^{3} \mathrm{~cm}^{-3}\right)$ computed from the volume concentration of coarse mode particle during the springtime (March, April, and May) of 2004-2006 as a threshold. Those days with hourly mean volume concentration of coarse mode particle exceeded this threshold were considered as candidates of the dust events in Beijing.

(2) AI values: The absorbing AI is a useful method to identify the dust events (e.g., Prospero et al., 2002). We checked the AI images on the candidate events selected by (1). It was found that the AI values over Beijing during those events were higher than 1. This confirms that dust events did occur in Beijing during these candidate days.

(3) Phenomenological dust storm observations: Chinese dust storm website (http://www.duststorm.com.cn/), operated by China Meteorological Administration (CMA), provides information on dust storm events occurred in China. The information on this website is derived from observations at more than 2000 surface observation stations located at different places in China. The dust events in Beijing identified by (1) and (2) have been reported on this website as the largescale dust storm events.

There was one severe dust storm event occurred on 17 April 2006, which was not identified by our measured data but reported by the Chinese dust storm website. During this event, the yellow dust falling in Beijing was estimated to be $330 \mathrm{k}$ tons (Yang et al., 2008). However, significant differences in the particle number size distributions between 17 April 2006 and non-dust days before and after were not observed in our size distribution measurements. The diameters of a major portion of the dust particles during this event might have exceeded $10 \mu \mathrm{m}$, the cutoff diameter of our system. This might be the reason why it was not observed by our ground based measurements. So, the dust event on 17 April 2006 will be excluded from the following discussions.

A total of 18 events have been identified in Beijing over the three years according the foregoing criterion in this study, of which 13 events took place in the spring of 2006. Yang et al. (2008) also indicated that the most dust storm events in China occurred in 2006 over the past seven years.

\subsection{Overview of dust events in Beijing}

Figure 1 displays the time series of the volume concentrations of total particles $\left(\mathrm{PV}_{10}\right)$ and coarse mode particles $\left(\mathrm{PV}_{\text {coarse }}\right)$ in the springs of 2004-2006. The 18 dust events have been marked and numbered as "DS\#" in Fig. 1. The dust events generally lead to large spikes in both $\mathrm{PV}_{10}$ and $\mathrm{PV}_{\text {coarse }}$ concentrations, as shown in Fig. 1. However, some peaks in $\mathrm{PV}_{10}$ concentrations on non-dust days were also observed. On these days, $\mathrm{PV}_{10}$ concentrations were comparable to those on some dust days, whereas, they were dominated by fine particles with the diameters smaller than $1 \mu \mathrm{m}$.

Table 1 lists the starting and ending time of the dust events, the duration time, mean $\mathrm{PV}_{\text {coarse }} / \mathrm{PV}_{10}$, and the meteorological parameters during the dust events. The event on 17 April 2006 (cf. DS12 in Fig. 1) is not included in both Tables 1 and 2.

The starting and ending time of the events was defined by the behaviour of the coarse mode particle number concentrations. The former was the time at which the coarse mode particle number concentration started to increase significantly, and the latter was the time at which the coarse mode particle number concentration decreased to the concentration level prior to the events or the average concentration level of coarse mode particles in the springs of 2004-2006. 


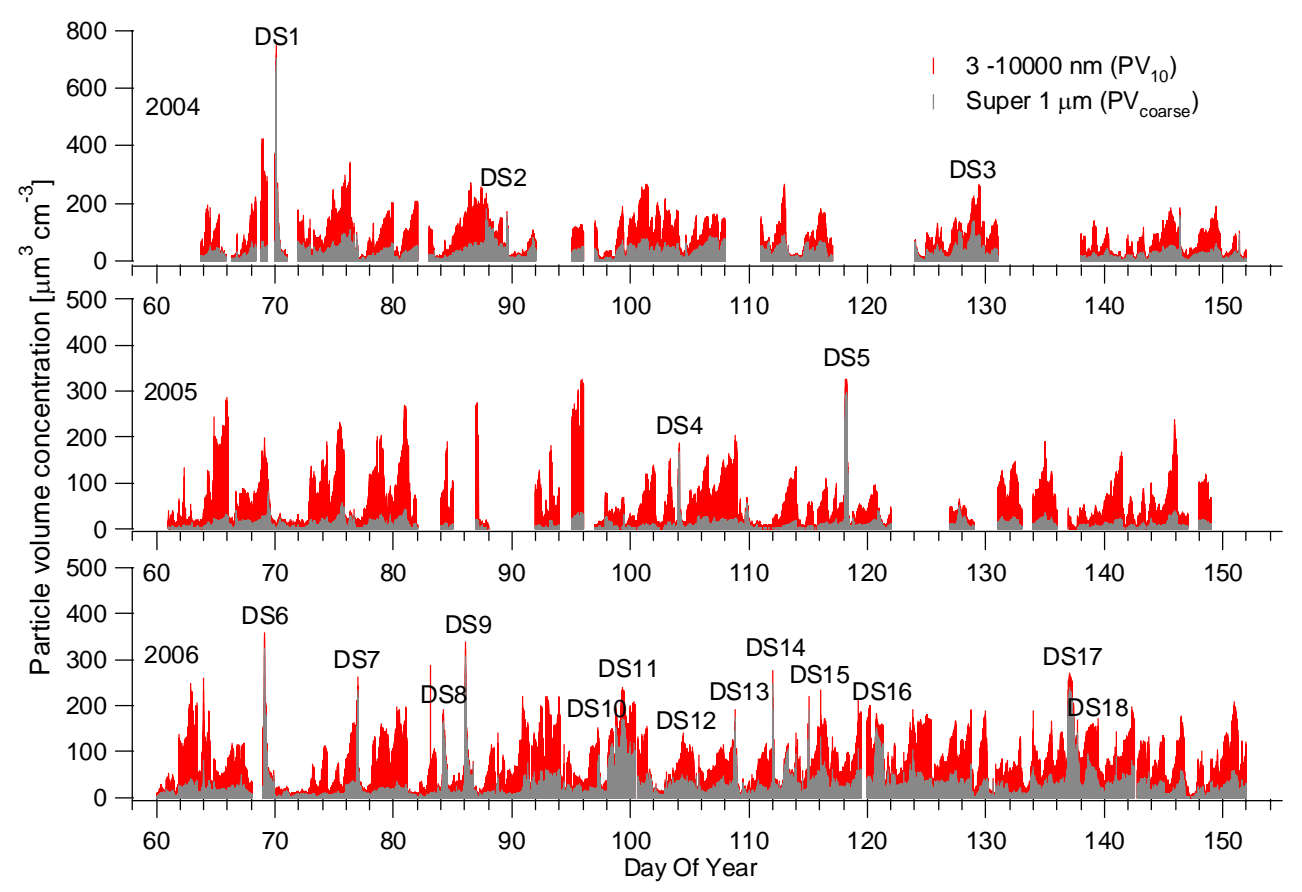

Fig. 1. Time series of volume concentrations of $\mathrm{PV}_{10}$ and $\mathrm{PV}_{\text {coarse }}$ during the springs of 2004, 2005, and 2006.18 dust events are labeled with "DS".

Most of the events took place in the early morning, particularly, their starting time lies between 00:00 and 05:00. Dust events mostly ended within $24 \mathrm{~h}$, except the events of DS2, DS3, DS11, and DS18. The event DS11 lasted more than 3 days with the longest duration time. Those dust events with a longer duration time are expected to have a stronger effect on the urban air quality and human health.

Coarse mode particles dominated $\mathrm{PV}_{10}$ for most of the events listed in Table 1, with a contribution of more than $70 \%$. On the contrary, the volume contribution of the coarse mode particles to $\mathrm{PV}_{10}$ for events DS2, DS3, DS11, DS16, and DS18 was much smaller $(0.68,0.50,0.58,0.65$ and 0.35 , respectively). As shown in Table 1, the average wind speeds during the events in most cases were higher than $4 \mathrm{~m} \mathrm{~s}^{-1}$ and the prevailing wind direction is north or northwest. Exceptions are DS3, DS11, DS16, and DS18 with wind speeds lower than $4 \mathrm{~m} \mathrm{~s}^{-1}$. The differences in $\mathrm{PV}_{\text {coarse }} / \mathrm{PV}_{10}$, the meteorological parameters, and the duration times between DS2, DS3, DS11, DS16, and DS18 and others indicate that there might be two different types of dust events. Here, they are respectively presented as type- 1 and type- 2 . The DS2, DS3, DS11, DS16, and DS18 are classified as type-2 and the rest as type-1. The event DS12 is not included in type- 1 or type- 2 .

The mean AOD, Ångström exponent, and refractive index (RI) during dust events are shown in Table 2. In order to gain insight into the effects of the dust events over year, the average columnar optical parameters in the four seasons of 2006 are presented in the last four rows of Table 2. Here, the four seasons were classified as spring (March-May), summer (June-August), fall (September-November), and winter (December-February). It was found that the lowest mean Ångström exponent was observed in spring, indicating a relatively high ratio of large particles to small particles due to dust loading in this season. The highest AOD and Ångström exponent were found during the summertime, implying that the AERONET sites in Beijing were mainly affected by the fine urban aerosols, but not by the coarse-mode particles. The similar results were also reported by Kim et al. (2007). The highest mean $n(\lambda)$ and the lowest mean $k(\lambda)$ were observed in spring of 2006. A similar seasonal variation of RI was reported by Yu et al. (2009) based on the AERONET data spanning from 2001 to 2007.

In Table 2, a significant difference in the columnar particle optical properties between DS2, DS3, DS11, DS16, and DS18 and other events is found. It supports the abovementioned categorization of dust events (type-1 and type-2). In the following sections, the particle number size distributions and particle optical properties for the two types will be discussed in detail.

\subsection{Dust particle number and volume size distributions}

In order to analyze the temporal evolution of particle number and volume size distributions during the events, two single events (Case 1 and 2) representing type- 1 and type-2 will be shown and discussed in this section in combination with back trajectories and AI images. The evolution of visibility 
Table 1. Summary of 18 dust events in Beijing. - indicates missing data.

\begin{tabular}{|c|c|c|c|c|c|c|c|}
\hline Number & $\begin{array}{l}\text { Starting } \\
\text { Time }\end{array}$ & $\begin{array}{l}\text { Ending } \\
\text { time }\end{array}$ & $\begin{array}{l}\text { Duration } \\
\text { time } \\
\text { [hh:mm] }\end{array}$ & $\begin{array}{l}\mathrm{PV}_{\text {coarse }} / \\
\mathrm{PV}_{10}\end{array}$ & $\begin{array}{l}\text { WS } \\
{\left[\mathrm{ms}^{-1}\right]}\end{array}$ & $\begin{array}{l}\mathrm{T} \\
{\left[{ }^{\circ} \mathrm{C}\right]}\end{array}$ & $\begin{array}{l}\mathrm{RH} \\
{[\%]}\end{array}$ \\
\hline DS1 & $\begin{array}{l}040310 \\
01: 40\end{array}$ & $\begin{array}{l}040310 \\
12: 00\end{array}$ & $10: 20$ & 0.89 & $\begin{array}{l}10.0 \\
\text { NW }\end{array}$ & 16 & - \\
\hline DS2 & $\begin{array}{l}040328 \\
02: 50\end{array}$ & $\begin{array}{l}040329 \\
14: 20\end{array}$ & $35: 30$ & 0.68 & $\begin{array}{l}3.0 \\
\text { NW }\end{array}$ & 19 & - \\
\hline DS3 & $\begin{array}{l}040506 \\
17: 00\end{array}$ & $\begin{array}{l}040508 \\
14: 00\end{array}$ & $45: 00$ & 0.50 & 1.5 & 21 & - \\
\hline DS4 & $\begin{array}{l}050414 \\
00: 40\end{array}$ & $\begin{array}{l}050414 \\
10: 00\end{array}$ & 09:20 & 0.83 & $5.9 \mathrm{~N}$ & 13 & 13 \\
\hline DS5 & $\begin{array}{l}050428 \\
03: 20\end{array}$ & $\begin{array}{l}50428 \\
10: 20\end{array}$ & 07:00 & 0.85 & $5.2 \mathrm{~N}$ & - & - \\
\hline DS6 & $\begin{array}{l}060310 \\
03: 10\end{array}$ & $\begin{array}{l}060310 \\
14: 50\end{array}$ & $11: 40$ & 0.83 & $\begin{array}{l}5.0 \\
\text { NW }\end{array}$ & - & - \\
\hline DS7 & $\begin{array}{l}060317 \\
21: 00\end{array}$ & $\begin{array}{l}060318 \\
09: 00\end{array}$ & $12: 00$ & 0.84 & $6.4 \mathrm{~N}$ & 10 & 15 \\
\hline DS8 & $\begin{array}{l}060325 \\
4: 30\end{array}$ & $\begin{array}{l}060325 \\
14: 20\end{array}$ & 09:50 & 0.83 & $4.6 \mathrm{~N}$ & - & - \\
\hline DS9 & $\begin{array}{l}060327 \\
01: 10\end{array}$ & $\begin{array}{l}060327 \\
14: 40\end{array}$ & $13: 30$ & 0.82 & $\begin{array}{l}4.6 \\
\text { NWN }\end{array}$ & - & - \\
\hline DS10 & $\begin{array}{l}060407 \\
04: 30\end{array}$ & $\begin{array}{l}060407 \\
14: 40\end{array}$ & $10: 10$ & 0.75 & $\begin{array}{l}4.7 \\
\text { NW }\end{array}$ & 17 & 13 \\
\hline DS11 & $\begin{array}{l}060408 \\
02: 30\end{array}$ & $\begin{array}{l}060411 \\
11: 40\end{array}$ & $81: 10$ & 0.58 & 1.0 & - & - \\
\hline DS13 & $\begin{array}{l}060418 \\
17: 10\end{array}$ & $\begin{array}{l}060418 \\
23: 50\end{array}$ & $06: 40$ & 0.84 & $\begin{array}{l}6.3 \\
\text { NW }\end{array}$ & 15 & 10 \\
\hline DS14 & $\begin{array}{l}060422 \\
00: 10\end{array}$ & $\begin{array}{l}060422 \\
08: 00\end{array}$ & $07: 50$ & 0.75 & - & - & - \\
\hline DS15 & $\begin{array}{l}060423 \\
00: 20\end{array}$ & $\begin{array}{l}060423 \\
12: 50\end{array}$ & $12: 30$ & 0.81 & - & - & - \\
\hline DS16 & $\begin{array}{l}060430 \\
12: 50\end{array}$ & $\begin{array}{l}060501 \\
10: 10\end{array}$ & $21: 20$ & 0.65 & 1.7 & 22 & 26 \\
\hline DS17 & $\begin{array}{l}060516 \\
22: 40\end{array}$ & $\begin{array}{l}060517 \\
21: 00\end{array}$ & $22: 20$ & 0.80 & $3.9 \mathrm{~N}$ & 24 & 16 \\
\hline DS18 & $\begin{array}{l}060518 \\
11: 00\end{array}$ & $\begin{array}{l}060519 \\
22: 00\end{array}$ & $35: 00$ & 0.35 & 1.5 & 25 & 49 \\
\hline
\end{tabular}

during these two cases will be also evaluated. Afterwards, the average number size distributions for type- 1 and type- 2 during the dust events were parameterized by using the lognormal fitting algorithm above-mentioned.

\subsubsection{Case 1: Observation of pure dust particles}

10 March 2006 was chosen as an example (case 1) associated with high wind speed (type-1). The time series of the particle number size distributions, the number and volume concentrations for different modes, wind speed and direction for case 1 are displayed in Fig. 2. The time series of visibility, the contributions of the coarse mode particles to the particle extinction, AOD $(440 \mathrm{~nm})$, and $\stackrel{\circ}{a}_{440}-870 \mathrm{~nm}$ are plotted in Fig. 3a.

Before the event, the particle number size distributions were characterized by maximum number concentrations in the Aitken and accumulation mode (cf. Fig. 2a, b). Such par-
Table 2. Summary of the mean columnar optical parameters during dust events. - indicates missing data.

\begin{tabular}{lllll}
\hline Events & AOD & Angström & $\mathrm{RI}(\mathrm{n}(\lambda))$ & $\mathrm{RI}(\mathrm{k}(\lambda))\left(\times 10^{-3}\right)$ \\
\hline DS1 & 0.38 & 0.11 & - & - \\
DS2 & 1.31 & 0.11 & $1.54 / 1.54 / 1.52 / 1.50$ & $5.1 / 1.8 / 2.1 / 2.1$ \\
DS3 & 1.31 & 1.05 & $1.51 / 1.54 / 1.55 / 1.54$ & $11.6 / 7.7 / 9.1 / 9.0$ \\
DS4 & - & - & - & - \\
DS5 & 0.41 & 0.20 & - & - \\
DS6 & 0.90 & -0.01 & $1.60 / 1.57 / 1.55 / 1.54$ & $4.0 / 0.9 / 0.8 / 0.8$ \\
DS7 & 0.19 & 0.33 & - & - \\
DS8 & - & - & - & - \\
DS9 & - & - & - & - \\
DS10 & 0.44 & 0.20 & - & - \\
DS11 & 1.62 & 0.41 & $1.56 / 1.57 / 1.57 / 1.56$ & $5.4 / 2.7 / 3.1 / 3.3$ \\
DS13 & - & - & - & - \\
DS14 & 0.34 & 0.25 & - & - \\
DS15 & 1.12 & -0.03 & $1.60 / 1.60 / 1.60 / 1.60$ & $5.4 / 2.7 / 3.1 / 3.3$ \\
DS16 & 1.24 & 0.51 & $1.55 / 1.57 / 1.58 / 1.57$ & $6.9 / 3.6 / 4.0 / 4.3$ \\
DS17 & 1.38 & 0.04 & $1.55 / 1.53 / 1.52 / 1.48$ & $3.5 / 1.8 / 1.9 / 2.0$ \\
DS18 & 2.52 & 0.51 & $1.48 / 1.48 / 1.48 / 1.47$ & $4.7 / 2.1 / 2.7 / 2.8$ \\
Spring & 1.04 & 0.69 & $1.52 / 1.55 / 1.56 / 1.56$ & $10.4 / 7.0 / 8.3 / 8.8$ \\
Summer & 1.18 & 1.19 & $1.44 / 1.46 / 1.47 / 1.48$ & $11.4 / 9.0 / 10.0 / 10.5$ \\
Fall & 0.92 & 1.09 & $1.49 / 1.51 / 1.51 / 1.53$ & $16.8 / 14.1 / 14.2 / 17.1$ \\
Winter & 0.65 & 1.08 & $1.49 / 1.52 / 1.53 / 1.53$ & $17.9 / 10.5 / 11.8 / 12.8$ \\
\hline
\end{tabular}

ticle number size distributions were typically observed under low wind speeds in the urban atmosphere of Beijing (Wu et al., 2008). The average visibility was lower than $5 \mathrm{~km}$, and the fine particle fraction contributed over $90 \%$ to the particle extinction (cf. Fig. 3a). High AOD (on average 1.45) and $\stackrel{\circ}{4}_{440-870 \mathrm{~nm}}$ (on average 0.95 ) caused by urban aerosols were observed.

At DOY (Day Of Year) of around 69.1, the dust storm reached the measurement site with a strong wind speed of more than $8 \mathrm{~m} \mathrm{~s}^{-1}$ (cf. Fig. 2d). A maximum total particle volume concentration of $380 \mu \mathrm{m}^{3} \mathrm{~cm}^{-3}$ was observed in the very beginning of the event, which was mainly caused by coarse mode particles ( $\sim 90 \%$, cf. Fig. 2a-c). As shown in Fig. 3a, we also found a dramatic change of the extinction contribution by the coarse mode particles, from about $5 \%$ to over $80 \%$. Interestingly, no similar break was observed in the evolution of the visibility. This result indicates that a severe dust storm could lead to a seriously low visibility in Beijing too (lower or about $5 \mathrm{~km}$ ). Afterwards, the visibility was increasing step by step with decreasing concentration of the coarse mode particles (cf. Fig. 3a), since the fine particles

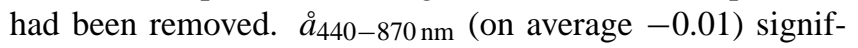
icantly dropped during daytime at DOY 69 due to the dust event. AOD values (on average 0.90) during the dust event are lower than those before. It is worth to note that the decrease in AOD is not very significant even though the particle volume concentration is significantly lower than before the event (also cf. Fig. 2). This implies that large amounts of dust particles still remained in higher altitudes.

Around noon (DOY $=69.5$ ), the number concentration of nucleation mode particles obviously increased, indicating the 
(a)
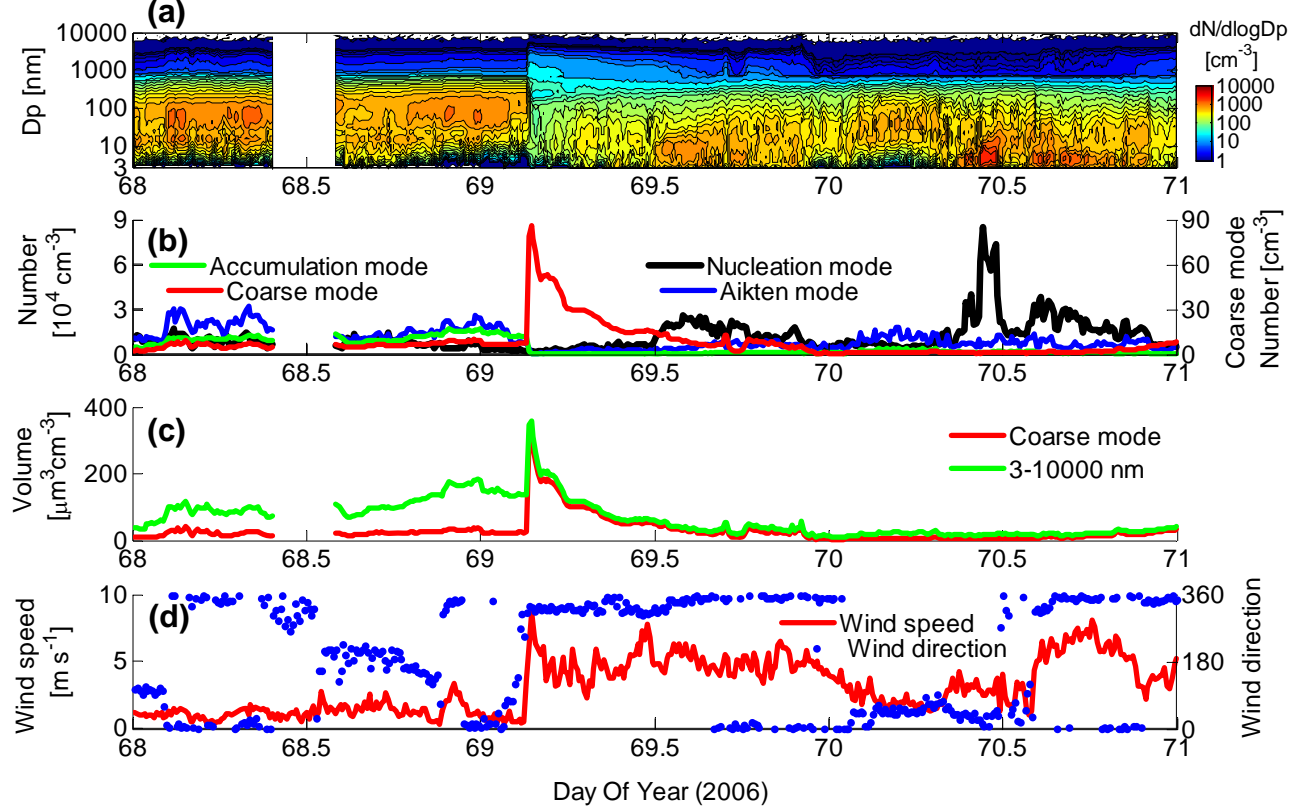

Fig. 2. Time series of particle size distribution, number and volume concentration for different aerosol particles modes, wind speed, and wind direction for case 1 .

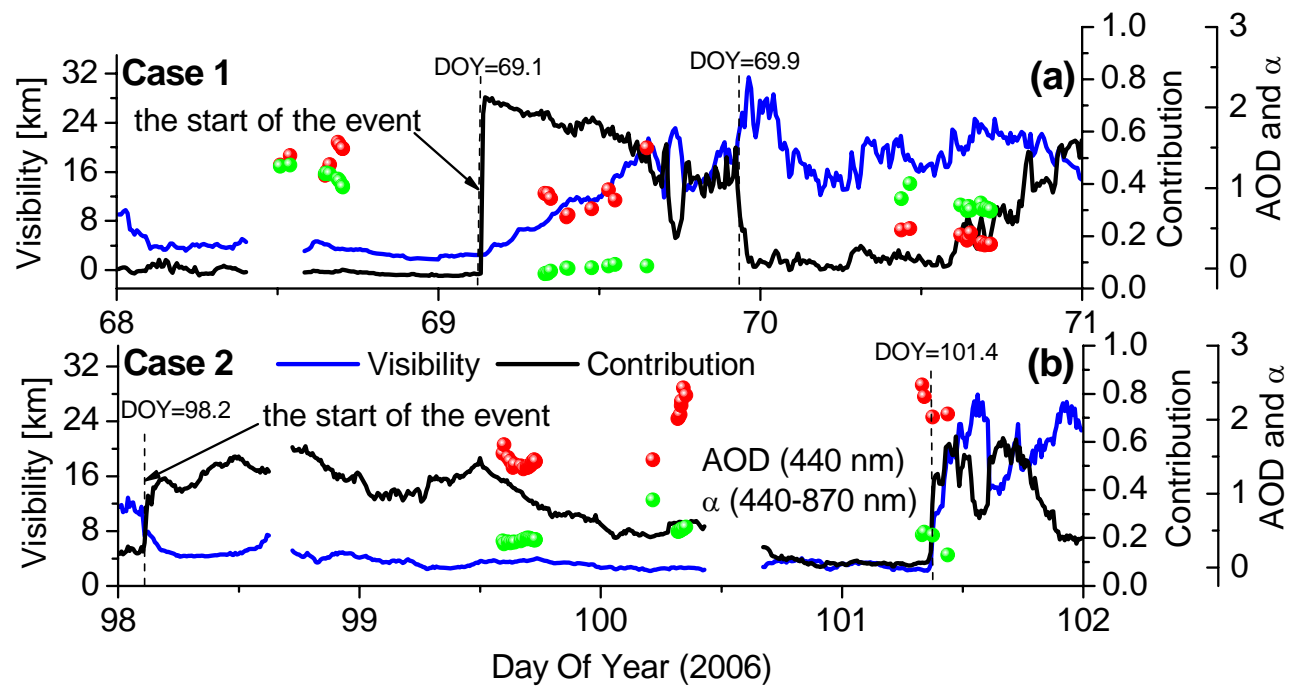

Fig. 3. Effects of dust events on visibility, the contribution of coarse mode particle to the extinction coefficient ("contribution"), Ångström exponent $(\alpha(440-870 \mathrm{~nm}))$, and AOD $(440 \mathrm{~nm})$ for case 1 and case 2.

occurrence of new particle formation and growth. Usually, the dust events observed in Beijing are associated with cold air advection behind a cold front. This leads to dry and pristine atmospheric conditions, which favors new particle formation. New particle formation after or during dust events was observed for all cases in type-1. The same phenomenon of new particle formation after dust events has been observed by Lee and Cho (2007) in South Korea.
The 2-day backward trajectories arriving at Beijing and the height above ground level (AGL) of the air parcels along the trajectories for case 1 are shown in Fig. 4. Back trajectories were calculated using the NOAA "HYSPLIT-4" trajectory model (Draxier and Hess, 1998). Before the event, the backward trajectories (1) and (2) are characterized by a short length, meaning slow movement of the air parcels. In Beijing, the transport speed of an air mass was found to play an essential role on the particle mass concentrations observed 

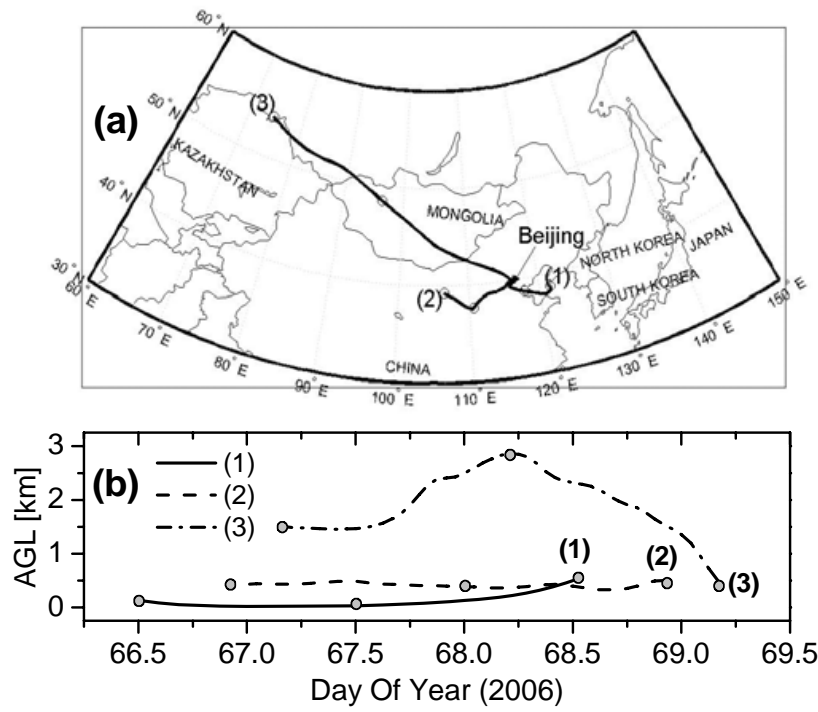

Fig. 4. The 2-day backward trajectories (a) and their height above ground level (AGL) (b) for case 1. Circles indicate 24 h-intervals.

in the urban area (Wehner, et al., 2008). Slow-moving air masses were shown to be associated with an effective accumulation of anthropogenic emissions. Also, it was evident that the air mass spent the last two days close to the surface (cf. Fig. 4b). This can explain the high concentrations of the accumulation and Aitken mode particles observed before the dust event. The back trajectory (3) shows the pathway of the air parcels arriving at the PKU site at the time when the event started. The air mass passed over Mongolia and Inner Mongolia (China), which are recognized as the major source regions of Asian dust.

To fully understand the source regions for case 1 , the TOMS AI images over eastern Asia were utilized. The AI images for 8, 9, 10, and 11 March 2006 are shown in Fig. 5. Global studies have shown that the typical AI values over major dust sources retrieved from TOMS are within the range from 0.5 to 3.0 (Prospero et al., 2002; Washington et al., 2003). Dey et al. (2004) reported that higher AI values (>3.7) over the Indo-Gangetic basin, India were observed during dust storm events. The AI on 9 March 2006 ranged from 1.0 to 4.0 , indicating the spreading of the dust in the atmosphere. On 10 March, the dust spreads over the North China Plain and the northeastern part of China, and Korea. Afterwards, the dust was transported to Japan on 11 March. Considering the image on 8 March 2006 and the back trajectory (3) shown in Fig. 4, it is confirmed that the dust observed in Beijing on 10 March 2006 originated from the desert areas in Mongolia and Inner Mongolia (China).

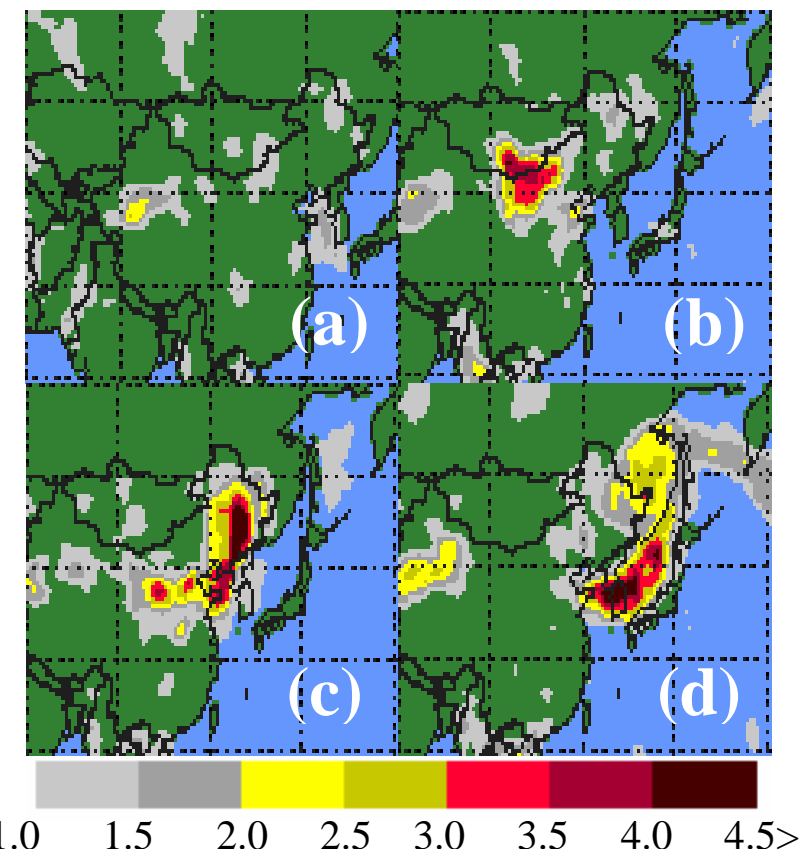

Fig. 5. Total Ozone Mapping Spectrometer (TOMS) aerosol index images showing the source and progressive movement of the dust particles during the dust storm events. (a) 20060308, (b) 20060309, (c) 20060310, (d) 20060311 .

\subsubsection{Case 2: Superposition of dust particles and urban aerosols}

Case 2 was chosen as a typical dust event with a low wind speed, which occurred on 8 April and ended on 11 April 2006. Similar patterns of the particle number size distributions were observed for other cases (DS2, DS3, DS16 and DS18) of Type-2. Figure 6 shows the temporal evolution of the particle number size distribution, the number and volume concentrations for the size-separated particles, and the wind speed and direction for case 2 . The evolution of the visibility, the contribution of the coarse mode particles to the particle extinction, AOD $(440 \mathrm{~nm})$, and $\stackrel{a}{4}_{440-870 \mathrm{~nm}}$ are plotted in Fig. 3b. The AERONET data are not available at DOY 98 due to the cloud contaminations.

At the beginning of the event, the particle number concentration in the coarse mode rose to $30 \mathrm{~cm}^{-3}$ within $2 \mathrm{~h}$. At the same time, the number concentrations of the Aitken mode and accumulation mode particles decreased with the increasing wind speed (cf. Fig. $6 \mathrm{~b}$ and c), but still kept at a high level (around $1 \times 10^{4} \mathrm{~cm}^{-3}$ ). From Fig. 3b, we can see a decrease in visibility with increasing concentration of coarse mode particles. The extinction contribution of the coarse mode particles is around 50\%, indicating that the coarse mode particles lead to decreasing visibility together with the fine mode particles $(<1 \mu \mathrm{m})$. 
(a)
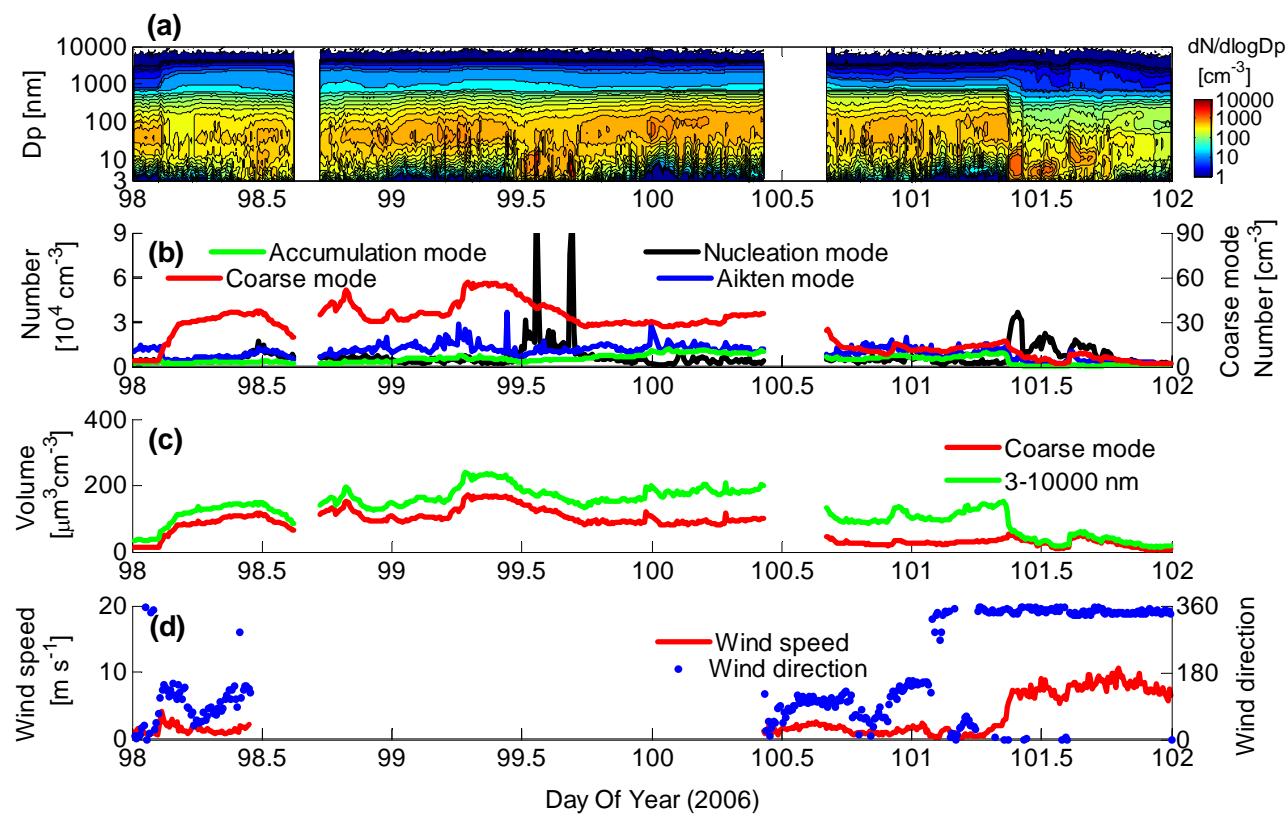

Fig. 6. Time series of particle size distribution, number and volume concentration for different aerosol particle modes, wind speed, and wind direction for case 2 .

Afterwards, the particle concentration kept nearly constant for one and a half day (cf. Fig. $6 \mathrm{~b}-\mathrm{c}$ ). The total particle volume concentrations were in the range from 150 to $200 \mu \mathrm{m}^{3} \mathrm{~cm}^{-3}$ most of the time. During the event, higher $\stackrel{\circ}{4}_{440-870 \mathrm{~nm}}$ (on average 0.41) and AOD (on average 1.62) were observed in contrast to those during the event in case 1. The former can be ascribed to the lower fraction of coarse mode particles. The latter is due to the superposition of dust particles and urban aerosols. The visibility during the whole event was less than $5 \mathrm{~km}$ (cf. Fig. 3b). On 11 April (DOY 101.4), the increase in wind speed resulted in a rapid decrease in the particle volume concentration followed by an increase in particle number concentration due to nucleation and growth.

The 2-day back trajectories at 500 and $1500 \mathrm{~m}$ for case 2 are shown in Fig. 7. The back trajectory (1) was initialized at the starting time of the event. Similar to case 1, the air mass passed over Mongolia and Inner Mongolia before arriving in Beijing. The back trajectories (2)-(4) display the pathway of air masses during the dust event at different times. The trajectories at $500 \mathrm{~m}$ (cf. 2a, 3a, and 4a in Fig. 7) with a short length arrived at the PKU site from easterly directions (cf. Fig. 7a) and spent most of their traveling time close to the surface (cf. Fig. 7b), i.e. over regions influenced by anthropogenic emissions east of Beijing. As afore-mentioned, such air masses are typically connected with high particle mass concentrations in Beijing. It is worth noticing that the directions of the back trajectories at $1500 \mathrm{~m}$ (cf. $2 \mathrm{~b}, 3 \mathrm{~b}$, and $4 \mathrm{~b}$ in Fig. 7) were different to those at $500 \mathrm{~m}$. These back trajectories display the pathway of the air parcels above the
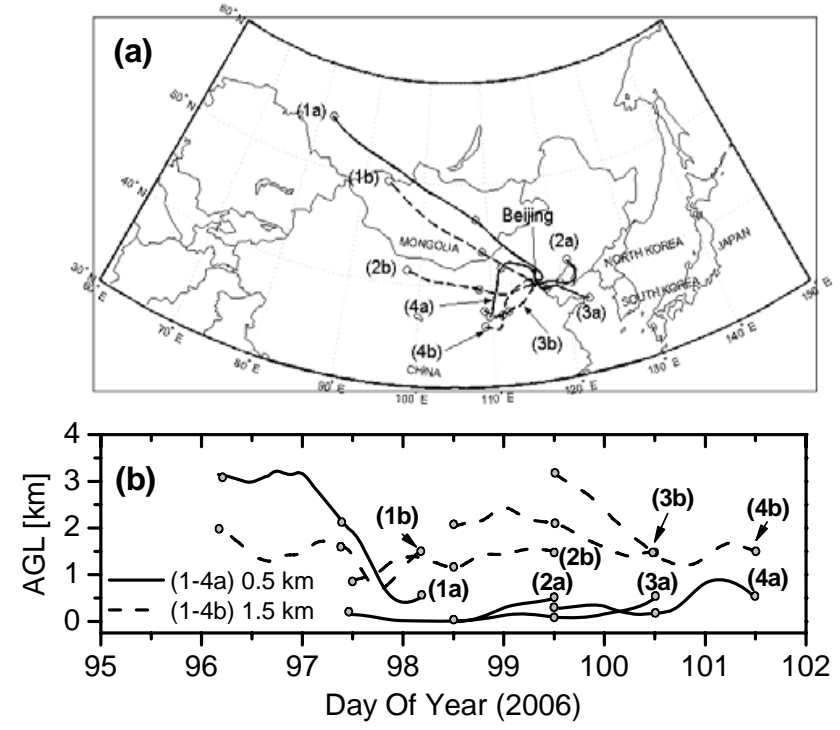

Fig. 7. The 2-day backward trajectories (a) and their height above ground level (AGL) (b) for case 2 arriving at 500- and 1500-m at the measurement site. Circles indicate $24 \mathrm{~h}$-intervals.

boundary layer where the dust was possibly lifted by convection and transported into the urban atmosphere of Beijing.

The AI images over East Asia for 6, 8, 9, and 10 April 2006 are shown in Fig. 8. The AI image for 6 April indicates areas from where the dust particles originated. The dust particles spread over Beijing on 7 April. At around 04:30 on 7 April, a dust event (DS10) with a short duration time was 


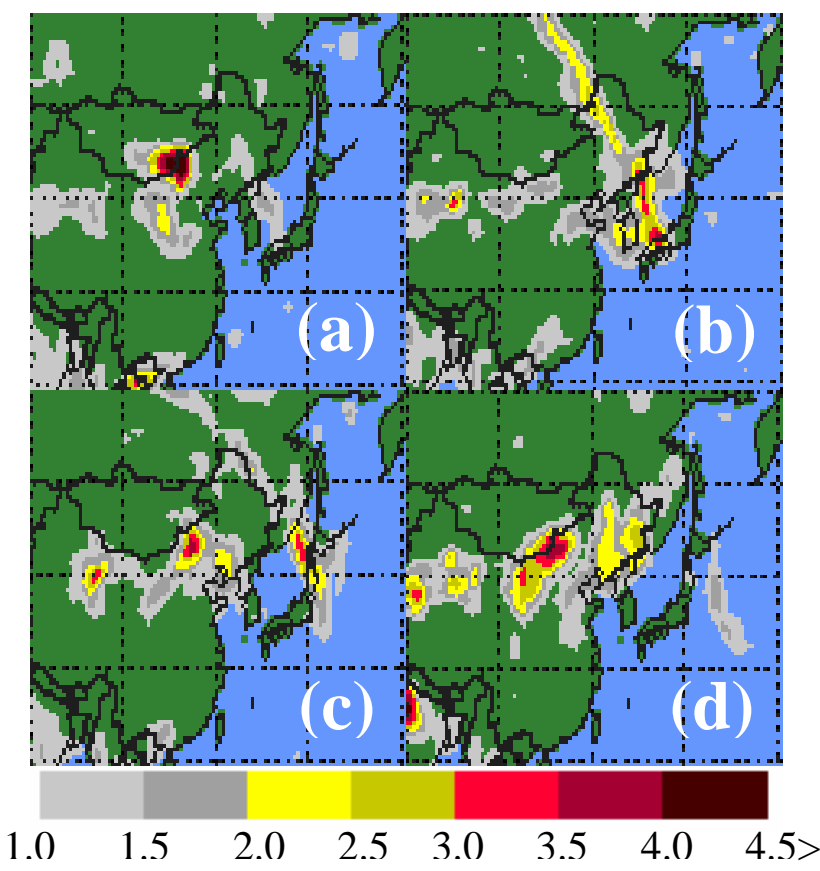

Fig. 8. Total Ozone Mapping Spectrometer (TOMS) aerosol index images showing the source and progressive movement of the dust particles during the dust storm events. (a) 20060406, (b) 20060408, (c) 20060409, (d) 20060410 .

observed in Beijing, and has been categorized into type-1. The event observed on 8 April was most likely the continuation of the event occurred on 7 April. It can be seen from Fig. 8 that the high AI values ( $>2.0$ ) over Inner Mongolia and Xinjiang Uygur Autonomous Region were found on two consecutive days (9 and 10 April 2006). It seems like that dust particles were produced continuously at these areas. This pattern is quite different from that for type- 1 . The AI values over Beijing were in the range of 1.5-2.0 during these two days, indicating high dust loadings in the atmosphere.

\subsubsection{General characteristics of type-1 and type-2 dust events}

In order to gain insight of the general characteristics of the two types of dust events, i.e., type- 1 and type-2, hourly mean number and volume size distributions were averaged over all cases of the two types at different times before and after the start of the dust event. The averaged particle number size distributions were parameterized by using the multi log-normal distribution function, as described in Sect. 2.4. The fitting parameters are listed in Table 3.

Figure 9a and c display the particle number and volume size distributions averaged at two hours before the start of the event and the first and the eighth hour after the start of the event for all the cases in type-1. The particle number size distributions can be categorized as three specific ones, representing three different processes of dust events. Two hours before the dust events, we observed typically urban aerosol size distributions representing a heavy polluted situation, i.e. a high number concentrations of Aitken mode and accumulation mode particles, as afore-mentioned (also cf. Fig. 2). The mode-fitting results show that GMDs for Aitken and accumulation mode are 70 and $214 \mathrm{~nm}$. The second process, which happened during the first hour of the dust events, was the transport-out of the anthropogenic aerosol and the import of dust particles. Typically, the highest concentrations of dust particles were observed in the very beginning of the event (cf. Fig. 2b-c). The GMD of the coarse mode particles was around $1.0 \mu \mathrm{m}$ without significant changes during dust events. The third process is new particle formation and growth, which causes an enhancement of the nucleation mode particle concentrations. From table 3, one can see that the GMD of the nucleation mode decreased to $6 \mathrm{~nm}$ eight hours after the start of the event.

The particle number and volume size distributions averaged over two hours before the start of the event and the first and the twelfth forward hour after the start of the event for all cases in type- 2 are shown in the right panel of Fig. 9. The average particle number size distribution of type- 2 before the start of the event, which is similar to type-1, was characterized by polluted urban aerosols. In contrast to type1, urban aerosols (Aitken and accumulation mode particles) were not transported out sufficiently because of the relatively low wind in the first hour after the start of the event. At the twelfth hour after the start of the event, the concentrations of the particles below $100 \mathrm{~nm}$ decreased accompanied by increasing accumulation mode particle concentrations compared to the beginning of the events. This may be caused by coagulation of small particles onto the bigger particles and condensational growth of small particles into accumulation mode size range under stable weather conditions. Meanwhile, the concentration of coarse mode particles reached its maximum. This resulted in mixing of dust particles and urban aerosols. The GMDs of the coarse mode particles for type-2 was around $1.3 \mu \mathrm{m}$.

As shown in Fig. 9b and d, both maxima of particle volume concentrations for type-1and type- 2 after the start of the event appeared are around $3 \mu \mathrm{m}$. Compared with type-1, the contribution of accumulation mode particles to the particle volume concentration was much larger. This suggests that if we performed the bulk sampling (e.g., $\mathrm{PM}_{10}$ filter measurements) during dust events for chemical analysis, the chemical composition for type- 1 and type- 2 would be different. Guo et al. (2004) analyzed elements of the total suspended particles (TSP, diameter $<100 \mu \mathrm{m}$ ) before, during, and after dust storm events occurred in the spring of 2001-2002 in Beijing. In comparison with elements in Inner Mongolia loess and Minqin dust, they found that if urban aerosols were effectively cleared out by strong wind, the TSP sampled during the dust event contained high fractions of purely crustal elements. This situation might be corresponding to type- 1 in our study. They also analyzed a weak dust event and found 

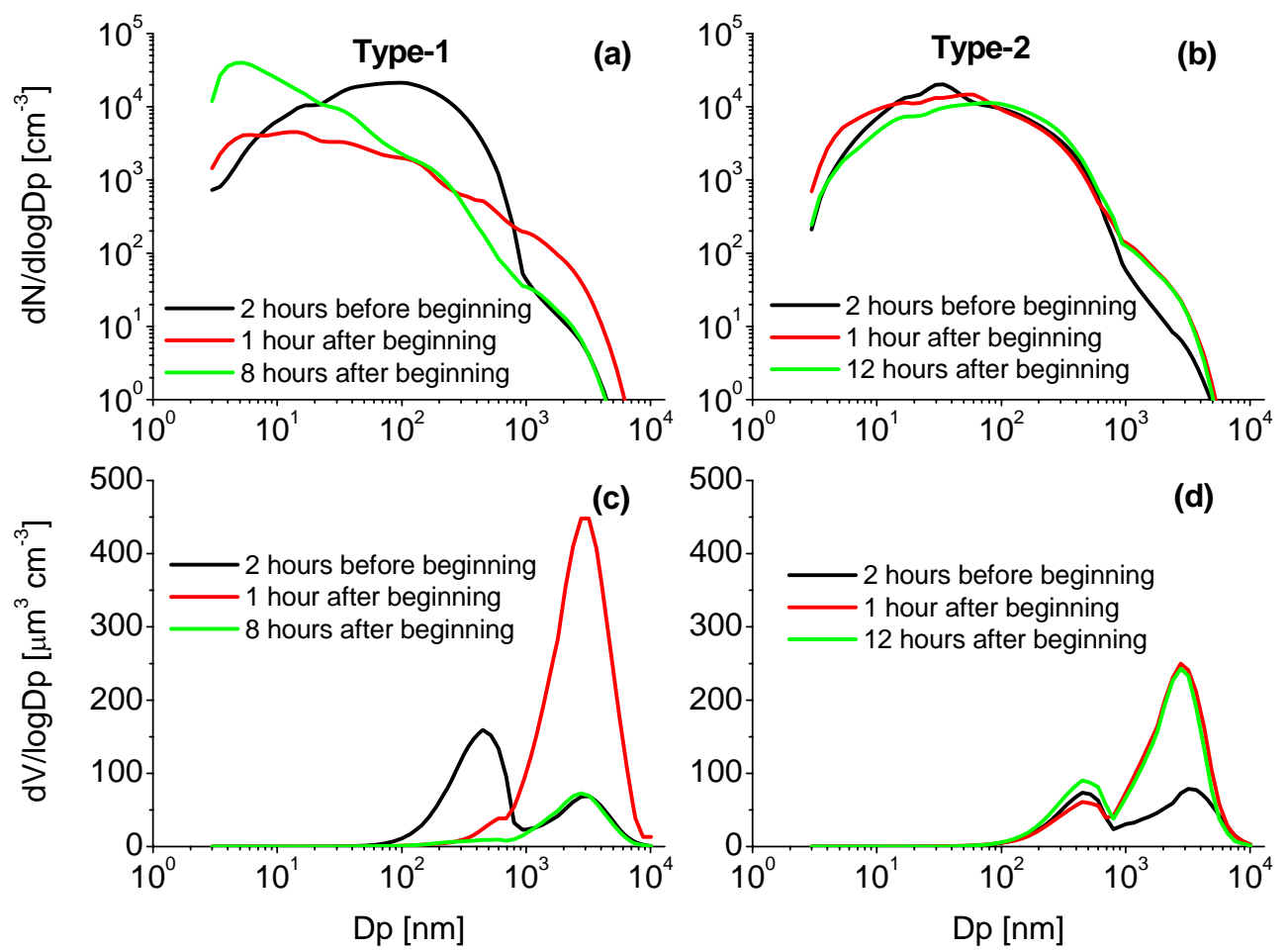

Fig. 9. Average number and volume size distributions for all type- 1 and type- 2 dust events in Beijing at different stages of the events.

Table 3. Parameters of log-normal mode fitting.

\begin{tabular}{|c|c|c|c|c|c|c|c|c|c|c|}
\hline & Type-1 & Type-2 & & & & & & & & \\
\hline & B2 & $1 \mathrm{~h}$ & $2 \mathrm{~h}$ & $3 \mathrm{~h}$ & $8 \mathrm{~h}$ & B2 & $1 \mathrm{~h}$ & $2 \mathrm{~h}$ & $3 \mathrm{~h}$ & $12 \mathrm{~h}$ \\
\hline$\overline{D p_{1}}$ & 17 & 7 & 9 & 8 & 6 & 16 & 10 & 12 & 11 & 11 \\
\hline$\sigma_{1}$ & 2.0 & 2.0 & 1.8 & 1.8 & 1.7 & 1.9 & 1.8 & 2.0 & 2.0 & 1.8 \\
\hline$N_{t, 1}$ & 6455 & 3131 & 6446 & 6927 & 22184 & 5829 & 5364 & 4018 & 4197 & 2307 \\
\hline$\frac{}{D p_{2}}$ & 70 & 34 & 34 & 32 & 25 & 39 & 44 & 47 & 49 & 46 \\
\hline$\sigma_{2}$ & 1.8 & 2.0 & 1.9 & 1.8 & 1.9 & 1.8 & 2.0 & 2.0 & 2.0 & 2.1 \\
\hline$N_{t, 2}$ & 13749 & 2189 & 2223 & 2109 & 6363 & 8960 & 10159 & 10205 & 10868 & 8066 \\
\hline$\frac{i, L}{D p_{3}}$ & 214 & 151 & 142 & 132 & 129 & 162 & 164 & 178 & 189 & 170 \\
\hline$\sigma_{3}$ & 1.6 & 2.0 & 1.9 & 1.9 & 1.9 & 1.8 & 1.9 & 1.8 & 1.7 & 1.8 \\
\hline$N_{t, 3}$ & 5093 & 843 & 784 & 771 & 894 & 3938 & 2843 & 3005 & 2883 & 4192 \\
\hline$\overline{D p_{4}}$ & 1629 & 1032 & 1050 & 1071 & 1174 & 1424 & 1305 & 1298 & 1298 & 1298 \\
\hline$\sigma_{4}$ & 1.5 & 1.7 & 1.7 & 1.7 & 1.6 & 1.6 & 1.6 & 1.6 & 1.6 & 1.6 \\
\hline$N_{t, 4}$ & 5.2 & 89 & 57 & 34 & 12 & 7 & 32 & 32 & 31 & 31 \\
\hline
\end{tabular}

in the case of superposition of urban pollutants and arrival of dust particles, that elements $(\mathrm{Cu}, \mathrm{Zn}$, and $\mathrm{S})$ involved in TSP were more derived from anthropogenic pollution. This case may correspond to type- 2 in our study.

Dust particles are considered to represent an important reactive surface for heterogeneous reactions, for example, reactions of $\mathrm{SO}_{2}, \mathrm{~N}_{2} \mathrm{O}_{5}, \mathrm{O}_{3}$, and $\mathrm{HO}_{2}$ radicals with mineral dust particles (Dentener et al., 1996). In the present study, the surface area concentrations of the coarse mode particles during the events were calculated and considered as an index for reactive surface of dust particles. The mean surface area concentration of coarse mode particles during dust event for type-1 was $230 \pm 180 \mu \mathrm{m}^{2} \mathrm{~cm}^{-3}$, which is four times larger than the mean value $\left(56 \pm 60 \mu \mathrm{m}^{2} \mathrm{~cm}^{-3}\right)$ derived by averaging over the three-year dataset (2004-2006) at the PKU site in Beijing. This value suggests that the dust particles may provide effective surface for heterogeneous reactions during the dust events in the urban atmosphere. The mean surface area concentration of the coarse mode particles during the event was $260 \pm 91 \mu \mathrm{m}^{2} \mathrm{~cm}^{-3}$ for type-2, which is 


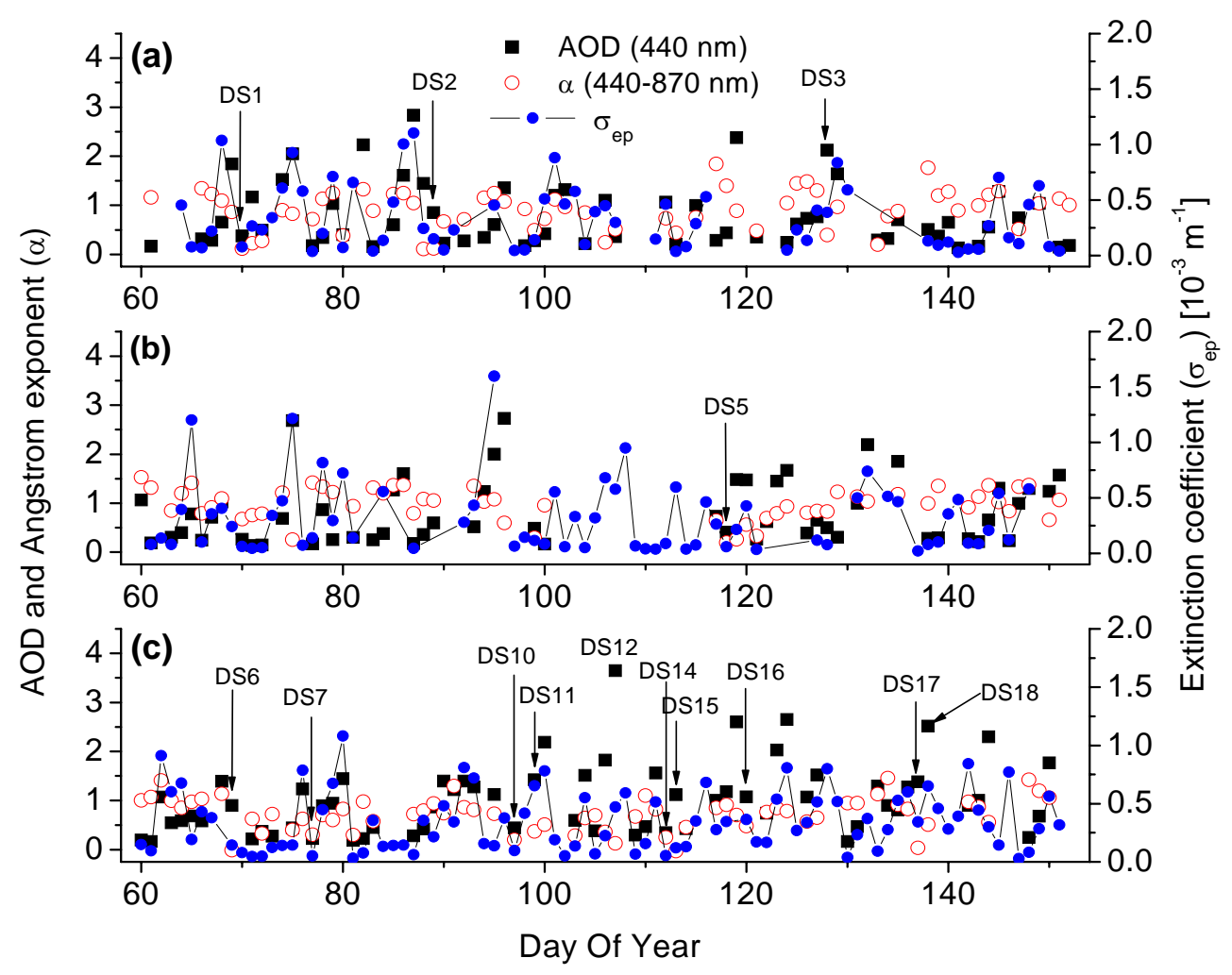

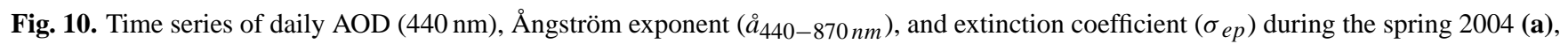
2005 (b), and 2006 (c). AERONET data for DS4, DS8, DS9, and DS18 are not available.

comparable to that of type- 1 . However, the gaseous pollutant concentrations were expected to be higher than those of type- 1 due to the low wind speeds. Moreover, the dust particle concentrations during the events in type- 2 maintained a high level for a much longer time than the events in type-1, as shown in Table 1. This fact may lead to a stronger interaction between dust particles and urban pollutants for type- 2 events.

\subsection{Comparisons between ground-based measurements and column integrated observations}

\subsubsection{Columnar optical parameters}

Time series of daily averaged AOD and $\stackrel{\circ}{440}_{440} 870 \mathrm{~nm}$ over Beijing, and mean extinction coefficient $\left(\sigma_{e p}\right)$ during daytime derived from averaging the time period between 08:00 and 17:00 (local time) in the spring seasons of 2004-2006 are shown in Fig. 10. The dust events have been marked in the figure. From Fig. 10, we can see that the variation pattern of the calculated extinction coefficient is similar to that of AOD.

The Ångström exponent characterizes the spectral features of the aerosol and it relates to the size of the particles (Shifrin, 1995). Low values of Ångström exponent indicate a relatively high ratio of large particles to small particles. As shown in Fig. 10, during the dust events, notable low values of $\stackrel{\circ}{a}_{440-870 \mathrm{~nm}}$ were found. This is attributed to the high column concentration of coarse mode particles due to the heavy dust loading. This phenomenon was also reported by other researchers, e.g., Kim et al. (2004), Ogunjobi et al. (2004), and Kim et al. (2008).

Ogunjobi et al. (2004) showed that dust days were associated with relatively higher AOD values than non-dust event days at Kwangju in South Korea. The similar phenomenon was also observed in Indo-Gangetic (IG) plains, Indian (Prasad and Singh, 2007). Unexpectedly, daily averaged AOD values in Beijing for some events were quite low, e.g., DS1, DS5, DS7 etc. It is worth noticing that the AOD values are available during daytime only. As shown in Figs. 1 and 10, those dust events with low daily averaged AOD values in Beijing started in the very early morning (cf. Table 1) followed by a rapid decrease of dust particles. Moreover, fine particles were effectively removed by strong winds. Therefore, the total particle volume concentration reached a low level during daytime. This may lead to very low AOD column values compared to urban pollution situations. For those events with high concentrations of dust particles during daytime, for example DS2, DS3, DS11, and DS17, higher AOD values were found (cf. Fig. 10). The maximum of AOD values with 3.65 is observed on 17 April 2006 (DOY = 107) where a severe dust storm event has been observed. 

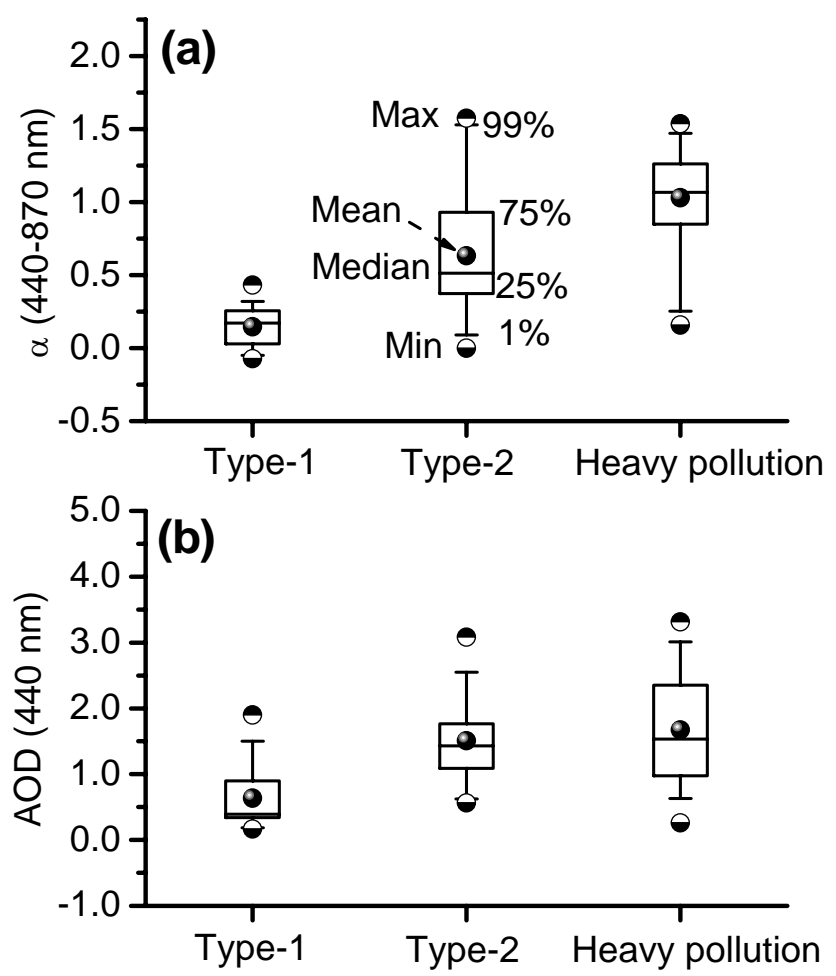

Fig. 11. Summary of the Ångström exponent and AOD for type-1 and type- 2 dust events, and heavy pollution periods.

Figure 11 presents the box plots of AOD and $\stackrel{\circ}{4}_{440-870 \mathrm{~nm}}$ for type-1, type- 2 , and heavy polluted periods. Here, the threshold for identifying heavy pollution periods is the upper 95 percent of hourly mean particle volume concentration $\left(173 \mu \mathrm{m}^{3} \mathrm{~cm}^{-3}\right)$ during the springs of 2004-2006 computed after excluding the dust events. This means that the times with a particle volume concentration larger than this threshold is considered as heavy pollution period, which represents the most serious pollution situation caused by anthropogenic aerosols in the springs in Beijing. During heavy polluted periods identified by using this method, a high Mie lidar extinction coefficient caused by spherical aerosols was observed. This confirmed that heavy air pollution due to high concentration of anthropogenic aerosols was observed in Beijing (cf. Sugimoto et al., 2003, 2006).

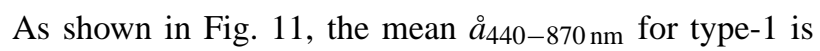
$0.18 \pm 0.13$ (average \pm standard deviation), which was lower than that for type- 2 with $0.63 \pm 0.40$. The reason is the higher contribution of submicron particles in type- 2 compared with type-1. Additionally, $\stackrel{\circ}{4}_{440-870 \mathrm{~nm}}$ in both dust event types was lower than those during heavy periods with an average of $1.03 \pm 0.31$. The average values of AOD for type-1, type-2, and heavy polluted periods were $0.36 \pm 0.23,1.51 \pm 0.59$, and $1.67 \pm 0.79$, respectively. AOD values for type- 2 are comparable with those for heavy periods, and significantly higher than those for type-1. This indicates that the superposition of dust particles and anthropogenic aerosols can result in much
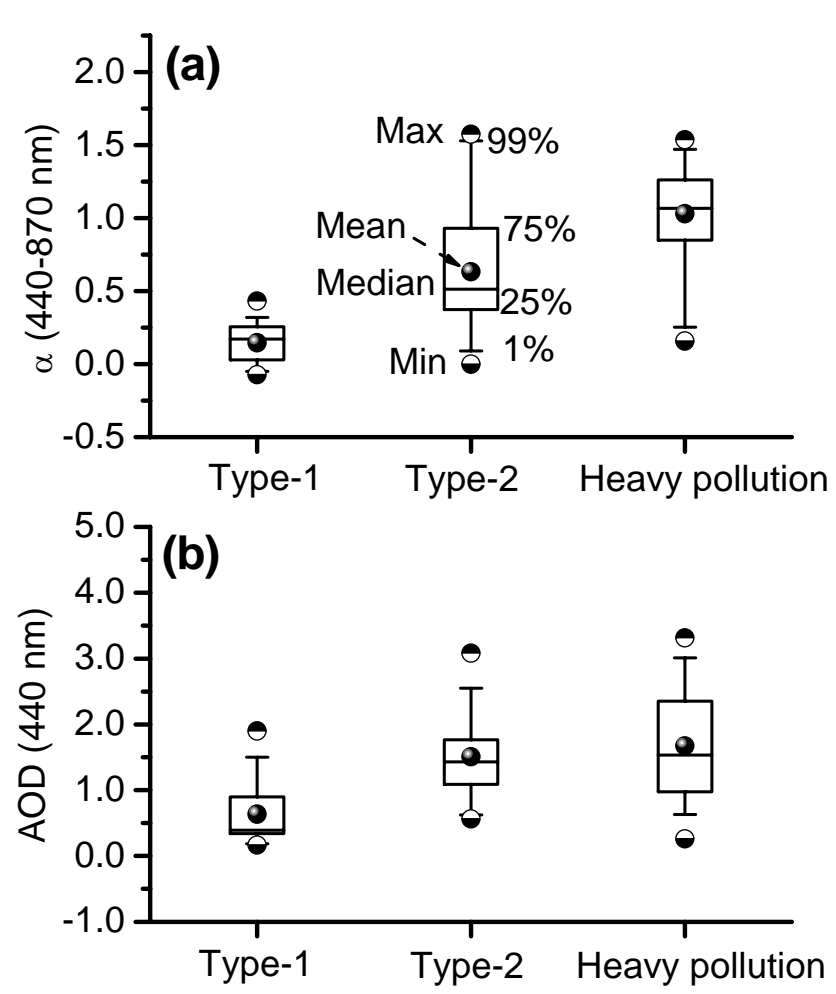

Fig. 12. Summary of real and imaginary parts of refractive index at the wavelength of $441,675,870,1020 \mathrm{~nm}$ for type- 1 and type- 2 dust events, and heavy pollution periods.

higher AOD than pure dust particles in the urban atmosphere of Beijing.

Figure 12 shows the statistical summary of the refractive index (real part: $\mathrm{n}(\lambda)$ and imaginary part: $\mathrm{k}(\lambda)$ ) at the wavelength of $441,675,870$, and $1020 \mathrm{~nm}$ for type-1, type-2, and heavy pollution periods. Typically, the higher $n(\lambda)$ and lower $k(\lambda)$ during dust events are observed compared to non-dust days (Dey et al., 2004; Prasad and Singh, 2007). This is consistent with our observations, as showed in Fig. 12. The mean $\mathrm{n}(\lambda)$ values for type- 1 and type- 2 are significantly higher than those for heavy pollution periods. An inverse pattern is observed for $\mathrm{k}(\lambda)$ (Fig. 12b). In contrast to type-1, the lower $\mathrm{n}(\lambda)$ and higher $\mathrm{k}(\lambda)$ are found for type- 2 due to the higher contribution of urban aerosols in type- 2 .

\subsubsection{Retrieved and measured particle volume size dis- tributions}

In this section, we will compare the particle volume size distributions retrieved from AERONET (http://aeronet.gsfc. nasa.gov/) and those calculated from TDMPS measurements. This provides insight into differences between ground-based and column integrated particle volume size distributions. Due to the different units, both particle volume size distributions derived from AERONET and TDMPS measurements were normalized. Since the size bins of the AERONET and 

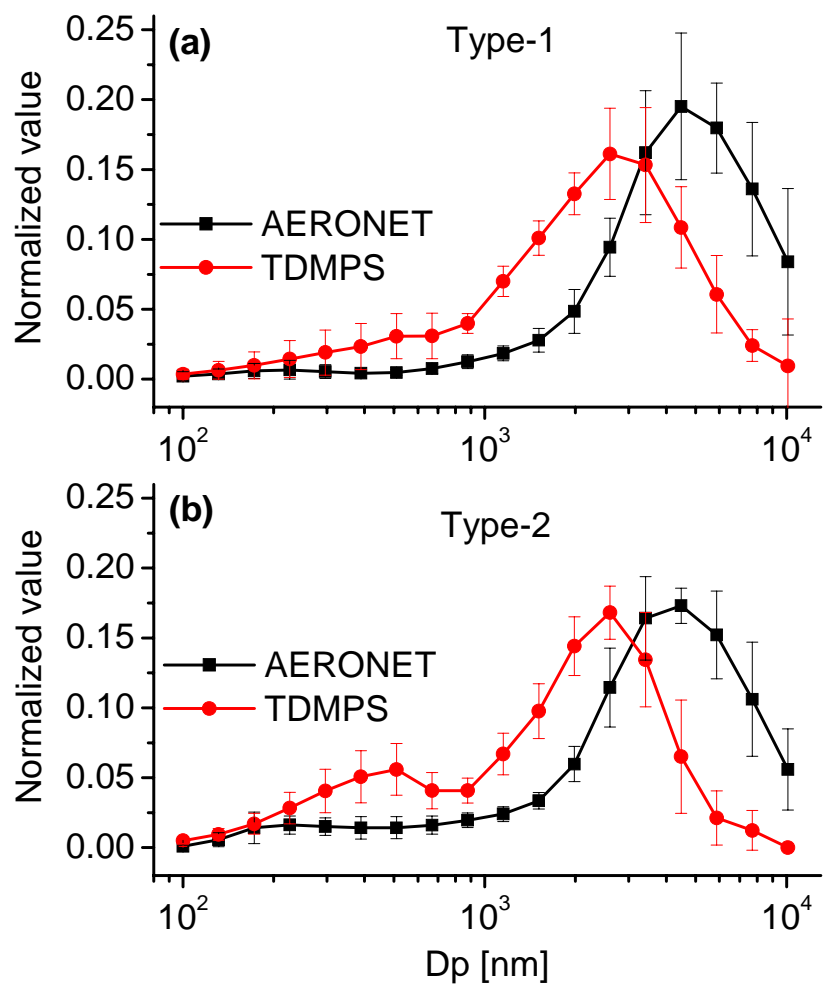

Fig. 13. Average normalized particle volume size distribution derived from AERONET and from TDMPS measurements for type-1 and type- 2 dust events.

TDMPS volume size distributions were different, the volume size distributions of TDMPS were interpolated to the size bins of AERONET ones. Afterwards, the volume size distributions derived from both methods were normalized by the respective total particle volume concentrations.

The mean normalized particle volume size distributions derived from AERONET and from TDMPS for type- 1 and type-2 are shown in Fig. 13. The peak concentrations of coarse mode particles obtained from TDMPS for type- 1 and type- 2 centered at around $3.0 \mu \mathrm{m}$, which was significantly smaller than the coarse mode peak diameters $(\sim 4.5 \mu \mathrm{m})$ retrieved from AERONET. The discrepancy may originate from the different accuracy of the methods to obtain the data between AERONET volume distributions and TDMPS ones. The expected accuracy of AERONET particle volume size distributions, which is $15-25 \%$ for dust particles larger than $0.5 \mu \mathrm{m}$ in radius (Dubovik and King, 2000; Dubovik et al., 2000), is lower than those of TDMPS and APS. Another possible reason is the vertical distributions of aerosol particles are not homogenous during dust events. Iwasaka et al. (2004) measured the particle vertical distributions using the balloon-borne measurements with an optical particle counter (OPC) at Dunhuang, China. They found that the particle size and concentration had noticeable peaks in super micron size range not only in the boundary mixing layer
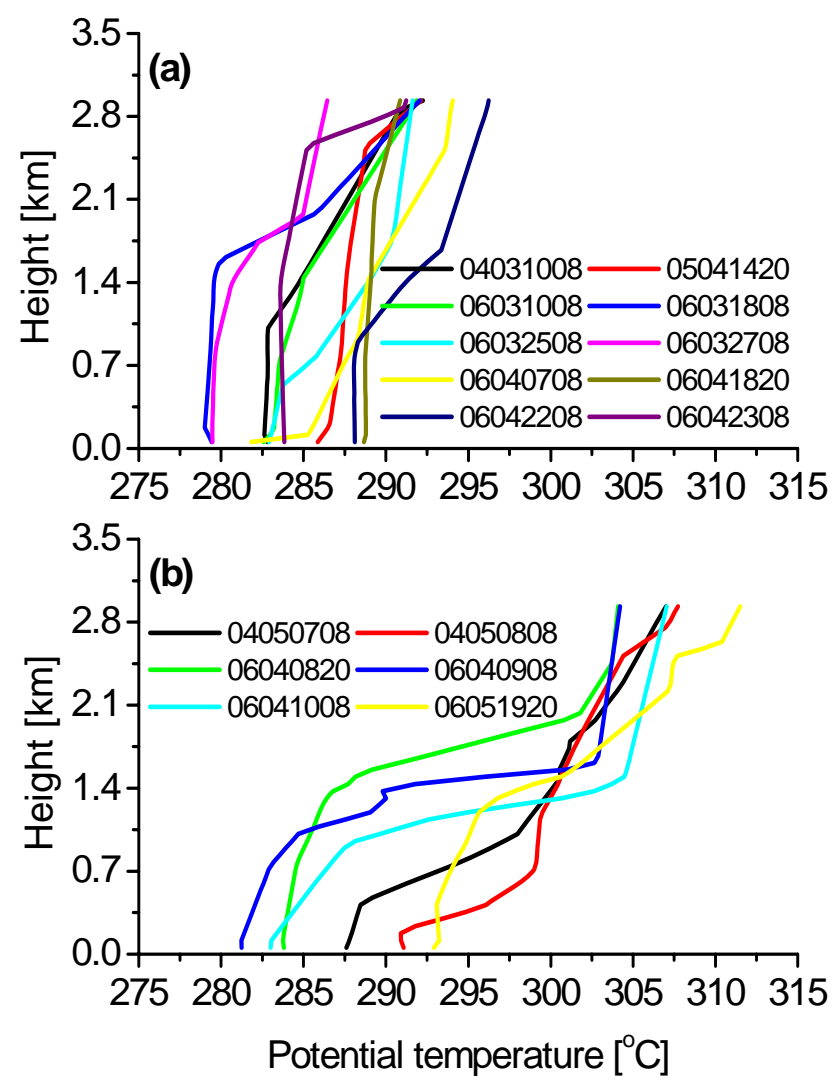

Fig. 14. The potential temperature profiles for dust events in type-1 (a) and type-2 (b) obtained from radiosoundings. Legend represents the local time. For example, 04031008 means 08:00 on 10 March 2004.

but also in the free troposphere and Super-micron particle concentration largely decreased in the mid tropopause (from 5 to $10 \mathrm{~km}$; above sea level). Because the AERONET volume distributions reflect the columnar integrated properties, the inhomogeneous vertical distributions may lead to the difference in columnar volume distributions and ground-based measurement.

On the other hand, it was found that one peak of the fine particles in the TDMPS volume size distribution occurred at $\sim 0.5 \mu \mathrm{m}$ for type-2, which was not observed in the AERONET retrieval one (cf. Fig. 13b). This phenomenon was not found for type-1. The peak in the ground-based measurements was obviously caused by anthropogenic aerosols, being trapped within the very low boundary layer. As a result, the peak in the submicron size range could not be identified by the column integrated volume size distributions. In order to confirm this, the radiosounding data (Source: University of Wyoming, http://weather.uwyo.edu/upperair/) were used to analyze the stability of the boundary layer during the dust events. The vertical profiles of the potential temperature for type- 1 and type- 2 are displayed in Fig. 14. Comparing type- 1 and type- 2 , it is obvious that the boundary layer 
during the events of type- 2 was much more stable than that of type-1. Therefore, the vertical mixing during the events of type-1 was more intense, which is in good agreement with the comparisons of the volume size distributions.

\section{Summary and conclusions}

The size distributions and optical properties of particles in the urban areas of Beijing, China during dust events in the springs of 2004-2006 were characterized based on threeyear continuous ground-based measurements of the particle number size distributions and AERONET sun/sky radiometer data. A total of 18 dust events were identified and further categorized as two different types (type- 1 and type-2). The identification and categorization of the dust events was confirmed by AI images, columnar aerosol optical properties, and vertical potential temperature profiles.

Type-1 dust events were associated with unstable weather conditions. High wind speeds (on average, $>4 \mathrm{~m} \mathrm{~s}^{-1}$ ) lead to an effective removal of anthropogenic aerosols. As a result, the dust particles dominated the total particle volume concentration $(3-10000 \mathrm{~nm})$ for over $70 \%$. Low visibility (lower or about $5 \mathrm{~km}$ ) was observed in the very beginning of the event for type- 1 due to the high dust loading. The events in type- 2 with a longer duration time and lower ratios of the coarse mode particle to the total particle volume concentration occurred under stable local weather conditions. During these events, the dust particles maintained a high concentration level for a relatively longer time compared to type-1. At the same time, stable meteorological conditions, favoring the accumulation of urban pollutants, led to a superposition of dust particles and anthropogenic aerosols. During the whole events in type-2, the visibility was kept very low. The extinction contribution by urban aerosols for type- 2 was significantly larger than that of type- 1 . The differences in duration time, meteorological conditions, and particle size distributions between type- 1 and type- 2 may imply different interactions of dust particles and anthropogenic pollutants, urban air quality, and health impacts between them. The backward trajectories and AI images show that the dust observed in Beijing may originate from the desert areas in Mongolia, Inner Mongolia and Xinjiang Uygur Autonomous Region of China.

The mean Ångström exponent for type- 1 is $0.18 \pm 0.13$, which is lower than that for type- 2 with $0.63 \pm 0.40$. This is consistent with the result that the ratios of small particles to larger particles for type- 2 are larger than those for type1. AOD values for type- 2 are comparable with those for the heavy pollution periods, and significantly higher than those for type-1. This indicates that the superposition of dust particles and anthropogenic aerosols can result in much higher AOD than relatively purer dust particles in the urban atmosphere of Beijing.
In this study, a comparison between the particle volume size distributions retrieved from AERONET and those obtained by TDMPS measurements is performed to gain insight into the differences in the ground-based and column integrated measurements. The peak diameters of coarse mode particles from the ground-based measurement are smaller than those from AERONET retrieved ones. The peak in the submicron size range for type- 2 caused by the urban aerosols was obvious in the ground-based measurement, but was not identified by the column integrated volume size distributions. In these cases, the urban aerosols might be trapped in the boundary layer near the ground, which was also confirmed by the analysis of the vertical stability using the radiosounding data.

Acknowledgements. This work was supported by the National Natural Science Foundation of China (20420130348), the National Basic Research Program (2002CB211605) and the "863" project (2006AA06A308), from Ministry of Science \& Technology, China, Beijing Council of Science and technology (HB200504-2), and by the Deutsche Forschungsgemeinschaft (DFG, WI 14449/9-1). The authors would like to thank Xiaoyang Liu and Jietai Mao for providing meteorological data and D. Müller and M. Tesche for their constructive comments. We greatly acknowledge the Principal Investigators for their effort in establishing and maintaining the AERONET Beijing sites, National Aeronautics and Space Administration (NASA) MODIS Team for providing AI images, and National Oceanic and Atmospheric Administration Air Resources Laboratory (NOAA ARL) for HYSPLIT transport and dispersion model.

Edited by: W. Birmili

\section{References}

Birmili, W., Wiedensohler, A., Heintzenberg, J., and Lehmann, K.: Atmospheric particle number size distribution in Central Europe: Statistical relations to air masses and meteorology, J. Geophys. Res., 106(D23), 32005-32018, 2001.

Bohren, C. F. and Huffman, D. R.: Absorption and scattering of light by small particles, New York, USA, John Wiley \& Sons, Inc., 1998.

Boy, J. and Wilcke, W.: Tropical Andean forest derives calcium and magnesium from Saharan dust, Global Biogeochem. Cy., 22(1), GB1027, doi:10.1029/2007GB002960, 2008.

Carrico, C. M., Bergin, M. H., Xu, J., Baumann, K., and Maring, H.: Urban aerosol radiative properties: measurements during the 1999 Atlanta Supersite Experiment, J. Geophys. Res., 108, D78422, doi:10.1029/2001JD001222, 2003.

Chan, C. K. and Yao, X.: Air pollution in mega cities in China, Atmos. Environ., 42, 1-42, 2008.

Cheng, Y. F., Heintzenberg, J., Wehner, B., Wu, Z. J., Su, H., Hu, M., and Mao, J. T.: Traffic restrictions in Beijing during the Sino-African Summit 2006: aerosol size distribution and visibility compared to long-term in situ observations, Atmos. Chem. Phys., 8, 7583-7594, 2008, http://www.atmos-chem-phys.net/8/7583/2008/. 
Dentener, F. J., Carmichael, G. R., Zhang, Y., Lelieveld J., and Crutzen, P. J.: Role of mineral aerosol as a reactive surface in the global troposphere, J. Geophys. Res., 101, 22869-22890, 1996.

DeCarlo, P. F., Slowik, J. G., Worsnop, D. R., Davidovits, P., and Jimenez, J. L.: Particle morphology and density characterization by combined mobility and aerodynamic diameter measurements, Part 1: Theory, Aerosol Sci. Tech., 38(12), 1185-1205, 2004.

Dey, S., Tripathi, S. N., and Singh, R. P.: Influence of dust stroms on the aerosol optical properties over the Indo-Gangetic basin, J. Geophys. Res., 109, D20211, doi:10.1029/2004JD004924, 2004.

Draxier, R. R. and Hess, G. D.: An overview of the HYSPLIT_4 modelling system for trajectories, dispersion and deposition, Aust. Meteorol. Mag., 47(4), 295-308, 1998

Dubovik, O. and King, M. D.: A flexible inversion algorithm for retrieval of aerosol optical properties from Sun and sky radiance measurements, J. Geophys. Res., 105, 20673-20696, 20000.

Dubovik, O., Smirnov, A., Holben, B. N., King, M. D., Kaufman, Y. J., Eck, T. F., and Slutsker, I.: Accuracy assessments of aerosol optical properties retrieved from Aerosol Robotic Network (AERONET) Sun and sky radiance measurements, J. Geophys. Res., 105, 9791-9806, 2000.

Eck, T. F., Holben, B. N., Reid, J. S., Dubovik, O., Smirnov, A., O'Neill, N. T., Slutsker, I., and Kinne, S.: Wavelength dependence of the optical depth of biomass, urban, and dust aerosols, J. Geophys. Res., 104, 31333-31349, 1999.

Eck, T. F., Holben, B. N., Ward, D. E., Dubovik, O., Reid, J. S., Smirnov, A., Mukelabai, M. M., Hsu, N. C., O’Neill, N. T., and Slutsker, I.: Characterization of the optical properties of biomass burning aerosols in Zambia during the 1997 ZIBBEE field campaign, J. Geophys. Res., 106, 3425-3448, 2001.

Fröhlich, C. and Shaw, G. E.: New determination of Rayleigh scattering in the terrestrial atmosphere, Appl. Opt., 19(11), 17731775, 1980.

Gao Y., Arimoto, R., Duce, R. A., Zhang, X. Y., Zhang, G. Y., An, Z. S., Chen, L. Q., Zhou, M. Y., and Gu, D. Y.: Temporal and spatial distributions of dust and its deposition to the China Sea, Tellus B., 49(2), 172-189, 1997.

Gong, S. L. and Zhang, X. Y.: CUACE/Dust - an integrated system of observation and modeling systems for operational dust forecasting in Asia, Atmos. Chem. Phys., 8, 2333-2340, 2008, http://www.atmos-chem-phys.net/8/2333/2008/.

Griffin, D. W. and Kellogg, C. A.: Dust storms and their impact on ocean and human health: Dust in Earth's atmosphere, EcoHealth, 1, 284-295, 2004.

Griffing, G. W.: Relations between the prevailing visibility, nephelometer scattering coefficient and sunphotometer turbidity coefficient, Atmos. Environ., 14, 577-584, 1980.

Groblicki, P. J., Wolff, G. T., and Countess, R. J.: Visibilityreduction species in the Denver "Brown Cloud" - I. Relationships between extinction and chemical composition, Atmos. Environ., 12, 2437-2484, 1981.

Guo, J., Rahn, K. A., and Zhuang, G. S.: A mechanism for the increase of pollution elements in dust storms in Beijing, Atmos. Environ., 38(6), 855-862, 2004.

Han, L. H., Zhuang, G. S., Cheng, S. Y., and Li, J.: The mineral aerosol and its impact on urban pollution aerosols over Beijing, China, Atmos. Environ., 41(35), 7533-7546, 2007.

Hänel, G.: Radiation budget of the boundary layer: Part II: Simultaneous measurement of mean solar volume absorption and ex- tinction coefficients of particles, Contrib. Atmos. Phys., 60, 241247, 1987.

Hasan, H. and Dzubay, T. G.: Apportioning light extinction coefficients to chemical species in atmospheric aerosol, Atmos. Environ., 17, 1573-1581, 1983.

Hinds, W. C.: Aerosol Technology: Properties, Behaviror and Measurements of Airborne Particles, John Wiley \& Sons, New York, USA, 49-50, 1982.

Holben, B. N., Tanre, D., Smirnov, A., Eck, T. F., Slutsker, I., Abuhassan, N., Newcomb, W. W., Schafer, J. S., Chatenet, B., Lavenu, F., Kaufman, Y. J., Castle, J. V., Setzer, A., Markham, B., Clark, D., Frouin, R., Halthore, R., Karneti, A., O'Neil, N. T., Pietras, C., Pinker, R. T., Voss, K., and Zibordi, G.: An emerging ground-based aerosol climatology: aerosol optical depth from AERONET, J. Geophys. Res., 106(11), 12067-12097, 2001.

Husar, R. B., Husar, J. D., and Martin, L.: Distribution of continental surface aerosol extinction based on visual range data, Atmos. Environ., 34, 5067-5078, 2000.

Husar, R. B., Tratt, D. M., Schichtel, B. A., Falke, S. R., Li, F., Jaffe, D., Gasso, S., Gill, T., Laulainen, N. S., Lu, F., Reheis, M. C., Chun, Y., Westphal, D., Holben, B. N., Gueymard, C., McKendry, I., Kuring, N., Feldman, G. C., McClain, C., Frouin, R. J., Merrill, J., DuBois, D., Vignola, F., Murayama, T., Nickovic, S., Wilson, W. E,. Sassen, K., Sugimoto, N., and Malm, W. C.: Asian dust events of April 1998, J. Geophys. Res., 106(D16), 18317-18330, 2001.

Hussein, T., Dal Maso, M., Petäjä, T., Koponen, I. K., Paatero, P., Aalto, P. P., Hämeri, K., and Kulmala, M.: Evaluation of an automatic algorithm for fitting the particle number size distributions, Boreal Env. Res., 10, 337-355, 2005.

In, H.-J. and Park, S.-U.: A simulation of long-range transport of Yellow Sand observed in April 1998 in Korea, Atmos. Environ., 36(26), 4173-4187, 2002.

Iwasaka, Y., Shi, G. Y., Kim, Y. S., Matsuki, A., Trochkine, D., Zhang, D., Yamada, M., Nagatani, T., Nagatani, M., Shen, Z., Shibata, T., and Nakata, H.: Pool of dust particles over the Asian continent: Balloon-borne optical particle counter and groundbased lidar measurements at Dunhuang, China, Environ. Monit. Assess., 92(1-3), 5-24, 2004.

Jo, C. O., Lee, J. Y., Park, K. A., Kim, Y. H., and Kim, K. R.: Asian dust initiated early spring bloom in the northern East/Japan Sea, Geophys. Res. Lett., L05602, doi:10.1029/2006GL027395, 2007.

Kent, G. S., Yue, G. K., Farrukh, U. O., and Deepak, A.: Modeling atmospheric aerosol backscatter at $\mathrm{CO}_{2}$ laser wavelengths, 1. Aerosol properties, modeling techniques, and associated problems, Appl. Opt., 22, 1655-1665, 1983.

Kim, J., Jung, C. H., Choi, B. C., Oh, S. N., Brechtel, F. J., Yoon, S. C., and Kim, S. W.: Number size distribution of atmospheric aerosols during ACE-Asia dust and precipitation events, Atmos. Environ., 41(23), 4841-4855, 2007.

Kim, D. H., Sohn, B. J., Nakajima, T., Takamura, T., Takemura, T., Choi, B. C., and Yoon, S. C.: Aerosol optical properties over east Asia determined from ground-based sky radiation measurements, J. Geophys. Res., 109, D02209, doi:10.1029/2003JD003387, 2004.

Kim, S. W., Yoon, S. C., and Kim, J.: Columnar Asian dust particle properties observed by sun/sky radiometers from 2000 to 2006 in Korea, Atmos. Environ., 42(3), 492-504, 2008. 
Kim, S. W., Yoon, S. C., Kim, J., and Kim, S. Y.: Seasonal and monthly variations of columnar aerosol optical properties over east Asia determined from multi-year MODIS, LIDAR, and AERONET Sun/sky radiometer measurements, Atmos. Environ., 41(8), 1634-1651, 2009.

Kurosaki, Y., and Mikami, M.: Recent frequent dust events and their relation to surface wind in East Asia, Geophys. Res. Lett., 30(14), 1736, 2003.

Lee, Y. G. and Cho, C. H.: Characteristics of Aerosol Size Distribution for a Severe Asian Dust Event Observed at Anmyeon, Korea in April 2006, J. Kor. Meteorol. Soc., 43(2), 87-96, 2007.

Mahowald, N. M., Baker, A. R., Bergametti, G., Brooks, N., Duce, R. A., Jickells, T. D., Kubilay, N., Prospero, J. M., and Tegen, I.: Atmospheric global dust cycle and iron inputs to the ocean, Global Biogeochem. Cy., 19(4), GB4025, doi:10.1029/2004GB002402, 2005.

Meier, J., Wehner, B., Massling, A., Birmili, W., Nowak, A., Gnauk, T., Brüggemann, E., Herrmann, H., Min, H., and Wiedensohler, A.: Hygroscopic growth of urban aerosol particles in Beijing (China) during wintertime: a comparison of three experimental methods, Atmos. Chem. Phys. Discuss., 9, 6889-6927, 2009, http://www.atmos-chem-phys-discuss.net/9/6889/2009/.

Meng, Z. Q. and Lu, B.: Dust events as a risk factor for daily hospitalization for respiratory and cardiovascular diseases in Minqin, China, Atmos. Environ., 41(33), 7048-7058, 2007.

Ogunjobi, K. O., He, Z., Kim, K. W., and Kim, Y. J.: Aerosol optical depth during episodes of Asian dust storms and biomass burning at Kwangju, South Korea, Atmos. Environ., 38(9), 1313-1323, 2004.

Okin, G. S., Mahowald, N., Chadwick, O. A., and Artaxo, P.: Impact of desert dust on the biogeochemistry of phosphorus in terrestrial ecosystems, Global Biogeochem. Cy., 18 (2), GB2005, doi:10.1029/2003GB002145, 2004.

Park, S. U. and Kim, J. W.: Aerosol size distributions observed at the Seoul National University campus in Korea during the Asian dust and non-Asian dust periods, Atmos. Environ., 40(9), 17221730, 2006.

Park, S. U. and In, H. J.: Parameterization of dust emission for the simulation of the yellow sand (Asian dust) event observed in March 2002 in Korea, J. Geophys. Res., 108(D19), 4618, doi:10.1029/2003JD003484, 2003.

Prasad, A. K. and Singh, R. P.: Changes in aerosol parameters during major dust storm events (2001-2005) over the Indo-Gangetic Plains using AERONET and MODIS data, J. Geophys. Res., 112, D09208, doi:10.1029/2006JD007778, 2007.

Prospero, J. M., Ginoux, P., Torres, O., Nicholson, S. E., and Gill, T. E.: Environmental characterization of global sources of atmospheric soil dust identified with the Nimbus 7 Total ozone Mapping Spectrometer (TOMS) absorbing aerosol product, Rev. Geophys., 40(1), 1002, doi:10.1029/2000RG000095, 2002.

Redemann, J., Turco, R. P., Liou, K. N., Russell, R. B., Bergstrom, R. W., Schmid, B., Livingston, J. M., Hobbs, R. V., Hartley, W. S., Ismail, S., Ferrare, R. A., and Browell, E. V.: Retrieving the vertical structure of the effective aerosol complex index of refraction from a combination of aerosol in situ and remote sensing measurements during TARFOX, J. Geophys. Res., 105(D8), 9949-9970, 2000.

Rosenfeld, D., Rudich, Y., and Lahav, R.: Desert dust suppressing precipitation: A possible desertification feedback loop. PNAS,
98, 5975-5980, 2001.

Schichtel, B. A., Husar, R. B., Falke, S. R., and Wilson, W. E.: Haze trends over the United States, 1980-1995, Atmos. Environ., 35, 5205-5210, 2001.

Schladitz, A., Müller, T., Massling, A., Kaaden, N., Kandler, K., and Wiedensohler, A.: In situ measurements of Optical Properties at Tinfou (Morocco) during the Saharan Mineral Dust Experiment SAMUM 2006, Tellus B., 61(1), 64-78, 2009.

Seinfeld, J. and Pandis, S.: Atmospheric chemistry and physics, New York, USA, John Wiley \& Sons, Inc., 1128 pp., 1998.

Shao, L. Y., Li, W. J., Yang, S. S., Shi, Z. B., and Lu, S. L.: Mineralogical characteristics of airborne particles collected in Beijing during a severe Asian dust storm period in spring 2002, Sci China Ser. D., 50(6), 953-959, 2007.

Shifrin, K. S.: Simple relationships between the Angstrom parameter of disperse system, Appl. Opt., 34, 4480-4485, 1995.

Sloane, C. S.: Optical properties of aerosols-comparison of measurements with model calculations, Atmos. Environ., 17, 409416, 1983.

Sloane, C. S.: Optical properties of aerosols of mixed composition, Atmos. Environ., 18(4), 871-878, 1984.

Sloane, C. S.: Effect of composition on aerosol light scattering efficiencies, Atmos. Environ., 20(5), 1025-1037, 1986.

Sloane, C. S., Watson, J., Chow, J., Pritchett, L., and Richards, L. W.: Size-segregated fine particle measurements by chemical species and their impact on visibility impairment in Denver, Atmos. Environ., 25A, 1013-1024, 1991.

Smirnov, A., Holben, B. N., Eck, T. F., Dubovik, O., and Slutsker, I.: Cloud screening and quality control algorithms for the AERONET database, Remote Sens. Environ., 73(3), 337-349, 2000.

Sokolik, I. N., and Toon, O. B.: Incorporation of mineralogical composition into models of the radiative properties of mineral aerosol from UV to IR wavelengths, J. Geophys. Res., 104(D8), 9423-9444, 1999.

Sun, Y. L., Zhuang, G. S., Wang, Y., Zhao, X. J., Li, J., Wang, Z. F., and An, Z. S.: Chemical composition of dust storms in Beijing and implications for the mixing of mineral aerosol with pollution aerosol on the pathway, J. Geophys. Res., 110(D24), D24209, doi:10.1029/2005JD006054, 2005.

Sugimoto, N., Uno, I., Nishikawa, M., Shimizu, A., Matsui, I., Dong, X., Chen, Y., and Quan, H.: Record Heavy Asian Dust in Beijing in 2002: Observations and Model Analysis of Recent Events, Geophys. Res. Lett., 30(12), 1640, doi:10.1029/2002GL016349, 2003.

Sugimoto, N., Shimizu, A., Matsui, I., Dong, X., Zhou, J., Bai, X., Zhou, J., Lee, C. H., Yoon, S. C., Okamoto, H., and Uno, I.: Network Observations of Asian Dust and Air Pollution Aerosols Using Two-Wavelength Polarization Lidars, in: The 23rd International Laser Radar Conference, Nara, Japan, July 2006, 851854, 2006.

Tanaka, T. Y. and Chiba, M.: A numerical study of the contributions of dust source regions to the global dust budget, Global Planet Change, 52(1-4), 88-104, 2006.

Tang, I. N. and Munkelwitz, H. R.: Water activities, densities and refractive indices of aqueous sulfates and sodium nitrate droplets of atmospheric importance, J. Geophys. Res., 99, 18801-18808, 1994.

Tegen, I., Werner, M., Harrison, S. P., and Kohfeld, K. E.: Rela- 
tive importance of climate and land use in determining present and future global soil dust emission, Geophys. Res. Lett., 31, L05105, doi:10.1029/2003GL019216, 2004.

Tomasi, C., Vitale, V., Petkov, B., Lupi, A., and Cacciari, A.: Improved algorithm for calculations of Rayleigh-scattering optical depth in standard atmospheres, Appl. Opt., 44(16), 3320-3341, 2005.

VanOsdell, D. W.: Test of the Rupprecht and Patashnick TEOM PM10 Sampler Inlet at 2 and $24 \mathrm{~km} \mathrm{~h}^{-1}$, Wind Tunnel Test Report No. 29A, NC, 1991.

Wang, Y., Zhuang, G. S., Sun, Y., and An, Z. S.: Water-soluble part of the aerosol in the dust storm season - evidence of the mixing between mineral and pollution aerosols, Atmos. Environ., 39(37), 7020-7029, 2005.

Wang, S., Yuan, W., and Shang, K.: The impacts of different kinds of dust events on PM10 pollution in Northern China, Atmos. Environ., 40(40), 7975-7982, 2006.

Washington, R., Todd, M., Middleton, N. J., and Goudie, A. S.: Dust storm source areas determined by the Total Ozone Monitoring Spectrometer and surface observations, Ann. Assoc. Am. Geogr., 93, 297-313, 2003.

Wehner, B., Birmili, W., Ditas, F., Wu, Z. J., Hu, M., Liu, X. Y., Mao, J. T., Sugimoto, N., and Wiedensohler, A.: Relationships between submicrometer particulate air pollution and air mass history in Beijing, China, 2004-2006, Atmos. Chem. Phys., 8, 6155-6168, 2008, http://www.atmos-chem-phys.net/8/6155/2008/.

Willeke, K. and Baron, P. A.: Aerosol Measurement Principles, Techniques, and Applications, Van Nostrand Reinhold, Hoboken, N. J., 97-102, 1993.

Wu, Z. J., Hu, M., Lin, P., Liu, S., Wehner, B., and Wiedensohler, A.: Particle number size distribution in the urban atmosphere of Beijing, China, Atmos. Environ., 42(34), 7967-7980, 2008.

Yang, D. Z., Ding, X. L., Yan, P., and Li, X. S.: Analysis on dust aerosols in "93.5.5" dust storm, in Research of Dust Storm in China, Meteorol. Press, Beijing, 103-110, 1997.
Yang, Y. Q., Hou, Q., Zhou, C. H., Liu, H. L., Wang, Y. Q., and Niu, T.: Sand/dust storm processes in Northeast Asia and associated large-scale circulations, Atmos. Chem. Phys., 8(1), 25-33, 2008.

Yu, X., Zhu, B., and Zhang, M.: Seasonal variability of aerosol optical properties over Beijing, Atmos. Environ., 43(26), 40954101, 2009.

Zender, C., Miller, R., and Tegen, I.: Quantifying mineral dust meass budgets: Sytematic terminology, constraints, and current estimates, EOS, 85, 509-512, 2004.

Zhang R. J., Arimoto R., An J. L., Yabuki S., and Sun J. H.: Ground observations of a strong dust storm in Beijing in March 2002, J. Geophys. Res., 110(D18), D18S06, doi:10.1029/2004JD004589, 2005.

Zhang, R. J., Wang, M. X., Pu, Y. F., Liu, Q., Fu, J. Z., and Zhang, W.: Analysis on the chemical and physical properties of "2000.4.6" super dust storm in Beijing, Clim. Environ. Res., 5, 259-266, (in Chinese with abstract in English), 2000.

Zhang, R. J., Wang, M. X., Zhang, X. Y., and Zhu, G. H.: Analysis on the chemical and physical properties of particles in a dust storm in spring in Beijing, Powder Technol., 37(1-2), 77-82, 2003.

Zhang, R., Arimoto, R., An, J., Yabuki, S., and Sun J.: Ground observations of a strong dust storm in Beijing in March 2002, J. Geophys. Res., 110, D18S06, doi:10.1029/2004JD004589, 2005.

Zhang, K. and Gao, H.: The characteristics of Asian-dust storms during 2000-2002: From the source to the sea, Atmos. Environ., 41(39), 9136-9145, 2007.

Zhang, X. Y., Gong, S. L., Zhao, T. L., Arimoto, R., Wang, Y. Q., and Zhou, Z. J.: Sources of Asian dust and role of climate change versus desertification in Asian dust emission, Geophys. Res. Lett., 30(24), 2272, 2003. 